\title{
Arbeidsmarktinformatie naar opleiding en beroep voor de provincie Noord-Holland
}

Citation for published version (APA):

Berendsen, H., de Grip, A., Wieling, M., \& Willems, E. J. T. A. (1992). Arbeidsmarktinformatie naar opleiding en beroep voor de provincie Noord-Holland. Researchcentrum voor Onderwijs en Arbeidsmarkt, Faculteit der Economische Wetenschappen. ROA Reports No. 3

https://doi.org/10.26481/umarep.1992003

Document status and date:

Published: 01/01/1992

DOI:

10.26481/umarep.1992003

Document Version:

Publisher's PDF, also known as Version of record

\section{Please check the document version of this publication:}

- A submitted manuscript is the version of the article upon submission and before peer-review. There can be important differences between the submitted version and the official published version of record.

People interested in the research are advised to contact the author for the final version of the publication, or visit the DOI to the publisher's website.

- The final author version and the galley proof are versions of the publication after peer review.

- The final published version features the final layout of the paper including the volume, issue and page numbers.

Link to publication

\footnotetext{
General rights rights.

- You may freely distribute the URL identifying the publication in the public portal. please follow below link for the End User Agreement:

www.umlib.nl/taverne-license

Take down policy

If you believe that this document breaches copyright please contact us at:

repository@maastrichtuniversity.nl

providing details and we will investigate your claim.
}

Copyright and moral rights for the publications made accessible in the public portal are retained by the authors and/or other copyright owners and it is a condition of accessing publications that users recognise and abide by the legal requirements associated with these

- Users may download and print one copy of any publication from the public portal for the purpose of private study or research.

- You may not further distribute the material or use it for any profit-making activity or commercial gain

If the publication is distributed under the terms of Article $25 \mathrm{fa}$ of the Dutch Copyright Act, indicated by the "Taverne" license above, 


\title{
ARBEIDSMARKTINFORMATIE NAAR OPLEIDING EN BEROEP
}

\author{
VOOR DE PROVINCIE NOORD-HOLLAND
}

ROA-R-1992/3

H. Berendsen

A. de Grip

M.H. Wieling

E.J.T.A. Willems

RESEARCHCENTRUM VOOR ONDERWIJS EN ARBEIDSMARKT

Rijksuniversiteit Limburg

Faculteit der Economische Wetenschappen

Maastricht, aprii 1992 


\section{CIP-GEGEVENS KONINKLIJKE BIBLIOTHEEK, DEN HAAG}

\section{Arbeidsmarktinformatie}

Arbeidsmarktinformatie naar opleiding en beroep voor de provincie Noord-Holland/ $H$. Berendsen...[et al.].-Maastricht: Researchcentrum voor Onderwijs en Arbeidsmarkt, Rijksuniversiteit Limburg, Faculteit der Economische Wetenschappen. -(ROA-R-1992/3)

Met lit. opg.

ISBN 90-5321-080-6 geb.

Trefw.: arbeidsmarkt ; Noord-Holland / onderwijs en arbeidsmarkt ; Noord-Holland. 


\section{INHOUDSOPGAVE}

Bladzijde

VERANTWOORDING

1. INLEIDING

2. ENKELE ACTUELE ARBEIDSMARKTGEGEVENS 3

2.1. Inleiding 3

2.2. Leeftijdsstructuur en conjunctuurgevoeligheid 3

2.3. Sectorstructuur 5

2.4. Beroeps- en opleidingsgegevens 6

3. STROMEN OP DE ARBEIDSMARKT 11

3.1. Inleiding 11

3.2. Uitbreidingsvraag 13

3.3. Vervangingsvraag 16

3.4. Baanopeningen 19

3.5. Instroom van schoolverlaters $\quad 22$

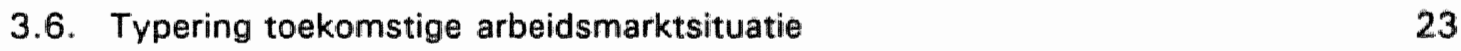

$\begin{array}{ll}\text { LITERATUUR } & 25\end{array}$

$\begin{array}{ll}\text { TABELLENOVERZICHT: } & 27\end{array}$

Algemene gegevens per provincie

Tabel 1. Leeftijdsopbouw werkzame bevolking per provincie (gemiddelde 1988-1990) 28

$\begin{array}{lll}\text { Tabel 2. Conjunctuurgevoeligheid per provincie } & 29\end{array}$

Provincie Noord-Holland: bedrijfssectorgegevens

Tabel 3. Aantal werkenden en percentage van de totale werkgellegenheid per bedrijfssector voor de provincie Noord-Holland (gemiddelde 1988-1990) 
Tabel 4. Aantal werkenden en percentage van de totale werkgelegenheid per beroepsklasse voor de provincie Noord-Holland (gemiddelde 1988-1990)

Tabel 5. Belangrijkste opleidingstypen per beroepsklasse voor de provincie Noord-Holland 1990

Tabel 6. Belangrijkste bedrijfssectoren per beroepsklasse voor de provincie Noord-Holland (gemiddelde 1988-1990)

Tabel 7. Uitbreidingswraag per beroepsklasse voor de provincie Noord-Holland 1989-1994 (absolute aantallen en als percentage van het aantal werkenden in 1989)

Tabel 8. Vervangingsvraag per beroepsklasse voor de provincie Noord-Holland 1989-1994 (absolute aantallen en als percentage van het aantal werkenden in 1989)

Tabel 9. Baanopeningen per beroepsklasse voor de provincie Noord-Holland 1989-1994 (absolute aantallen en als percentage van het aantal werkenden in 1989)

Provincie Noord-Holland: opleidingstypegegevens

Tabel 10. Aantal werkenden en percentage van de totale werkgelegenheid per opleidingstype voor de provincie Noord-Holland 1990

Tabel 11. Belangrijkste beroepsklassen per opleidingstype voor de provincie Noord-Holland 1990

Tabel 12. Belangrijkste bedrijfssectoren per opleidingstype voor de provincie Noord-Holland 1990

Tabel 13. Werkloosheidspercentage per opleidingstype voor de provincie Noord-Holland april 1991 (bemiddelingsbestand zonder baan)

Tabel 14. Bedrijfssectorspreiding per opleidingstype voor de provincie Noord-Holland 1990 (Gini-Hirschman indicator)

Tabel 15. Uitbreidingsvraag per opleidingstype voor de provincie Noord-Holland 1989-1994 (absolute aantallen en als percentage van het aantal werkenden in 1989) 
Tabel 16. Vervangingsvraag per opleidingstype voor de provincie Noord-Holland 1989-1994 (absolute aantallen en als percentage van het aantall werkenden in 1989)

Tabel 17. Baanopeningen per opleidingstype voor de provincie Noord-Holland 1989-1994 (absolute aantallen en als percentage van het aantal werkenden in 1989)

Tabel 18. Instroom van schoolverlaters per opleidingstype voor de provincie Noord-Holland 1989-1994 (absolute aantallen en als percentage van het aantal werkenden in 1989)

Tabel 19. Toekomstige arbeidsmarktsituatie per opleidingstype voor de provincie Noord-Holland 1989-1994

Algemene gegevens per RBA-gebied

Tabel 20. Leeftijdsopbouw werkzame bevolking per RBA-gebied (gemiddelde 1989-1990)

Tabel 21. Conjunctuurgevoeligheid per RBA-gebied

RBA-gebied Gooi en Vechtstreek: bedrijfssectorgegevens

Tabel 22. Aantal werkenden en percentage van de totale werkgelegenheid per bedrijfssector voor het RBA-gebied Gooi en Vechtstreek (gemiddelde 1989-1990)

RBA-gebied Gooi en Vechtstreek: beroepsklassegegevens

Tabel 23. Aantal werkenden en percentage van de totale werkgelegenheid per beroepsklasse voor het RBA-gebied Gooi en Vechtstreek (gemiddelde 1989-1990)

RBA-gebied Gooi en Vechtstreek: opleidingstypegegevens

Tabel 24. Aantal werkenden en percentage van de totale werkgelegenheid per opleidingstype voor het RBA-gebied Gooi en Vechtstreek 1990

Tabel 25. Werkloosheidspercentage per opleidingstype voor het RBA-gebied Gooi en Vechtstreek april 1991 (bemiddelingsbestand zonder baan)

Tabel 26. Bedrijfssectorspreiding per opleidingstype voor het RBA-gebied Gooi en Vechtstreek 1990 (Gini-Hirschman indicator) 
Tabel 27. Aantal werkenden en percentage van de totale werkgelegenheid per bedrijfssector voor het RBA-gebied Noord-Holland Noord (gemiddelde 1989-1990)

RBA-gebied Noord-Holland Noord: beroepsklassegegevens

Tabel 28. Aantal werkenden en percentage van de totale werkgelegenheid per beroepsklasse voor het RBA-gebied Noord-Holland Noord (gemiddelde 1989-1990)

RBA-gebied Noord-Holland Noord: opleidingstypegegevens

Tabel 29. Aantal werkenden en percentage van de totale werkgelegenheid per opleidingstype voor het RBA-gebied Noord-Holland Noord 1990

Tabel 30. Werkloosheidspercentage per opleidingstype voor het RBA-gebied Noord-Holland Noord april 1991 (bemiddelingsbestand zonder baan)

Tabel 31. Bedrijfssectorspreiding per opleidingstype voor het RBA-gebied Noord-Holland Noord 1990 (Gini-Hirschman indicator)

RBA-gebied Amsterdam/Zaanstreek/Waterland: bedrijfssectorgegevens

Tabel 32. Aantal werkenden en percentage van de totale werkgelegenheid per bedrijfssector voor het RBA-gebied Amsterdam/Zaanstreek/Waterland (gemiddelde 1989-1990)

RBA-gebied Amsterdam/Zaanstreek/Waterland: beroepsklassegegevens

Tabel 33. Aantal werkenden en percentage van de totale werkgelegenheid per beroepsklasse voor het RBA-gebied Amsterdam/Zaanstreek/Waterland (gemiddelde 1989-1990)

RBA-gebied Amsterdam/Zaanstreek/Waterland: opleidingstypegegevens

Tabel 34. Aantal werkenden en percentage van de totale werkgelegenheid per opleidingstype voor het RBA-gebied Amsterdam/Zaanstreek/Waterland 1990

Tabel 35. Werkloosheidspercentage per opleidingstype voor het RBA-gebied Amsterdam/Zaanstreek/Waterland april 1991 (bemiddelingsbestand zonder baan) 
Tabel 36. Bedrijfssectorspreiding per opleidingstype voor het RBA-gebied Amsterdam/Zaanstreek/Waterland 1990 (Gini-Hirschman indicator)

RBA-gebied Kennemer-/Amstel- en Meerlanden: bedrijfssectorgegevens

Tabel 37. Aantal werkenden en percentage van de totale werkgelegenheid per bedrijfssector voor het RBA-gebied Kennemer-/Amstel- en Meerlanden (gemiddelde 1989-1990)

RBA-gebied Kennemer-/Amstel- en Meerlanden: beroepsklassegegevens

Tabel 38. Aantal werkenden en percentage van de totale werkgelegenheid per beroepsklasse voor het RBA-gebied Kennemer-/Amstel- en Meerlanden (gemiddelde 1989-1990)

RBA-gebied Kennemer-/Amstel- en Meerlanden: opleidingstypegegevens

Tabel 39. Aantal werkenden en percentage van de totale werkgelegenheid per opleidingstype voor het RBA-gebied Kennemer-/Amstel- en Meerlanden 1990

Tabel 40. Werkloosheidspercentage per opleidingstype voor het RBA-gebied Kennemer-/Amstel- en Meerlanden april 1991 (bemiddelingsbestand zonder baan)

Tabel 41. Bedrijfssectorspreiding per opleidingstype voor het RBA-gebied Kennemer-/ Amstel- en Meerlanden 1990 (Gini-Hirschman indicator) 


\section{VERANTWOORDING}

In opdracht van het Ministerie van Onderwijs en Wetenschappen heeft het Researchcentrum voor Onderwijs en Arbeidsmarkt (ROA) de afgelopen jaren het informatiesysteem onderwijsarbeidsmarkt ontwikkeld. Onlangs is nagegaan in hoeverre de verschillende elementen van dit tot op heden landelijke ROA-informatiesysteem ook op regionaal niveau zouden kunnen worden gepresenteerd (zie Berendsen, De Grip, Wieling en Willems, 1992a). Deze regionale invalshoek heeft daarbij voornamelijk betrekking op een uitsplitsing naar provincie. In dit rapport wordt bij wijze van voorbeeld de beschikbare arbeidsmarktinformatie voor de provincie Noord-Holland gepresenteerd. Het onderzoek is behalve door het Ministerie van Onderwijs en Wetenschappen gefinancierd door het Centraal Bestuur voor de Arbeidsvoorziening (CBA) en het Landelijk Dienstverlenend Centrum voor studie- en beroepskeuzevoorlichting (LDC).

Het onderzoek werd uitgevoerd door drs. H. Berendsen, dr. A. de Grip (projectleider), drs. M.H. Wieling en drs. E.J.T.A. Willems. De auteurs danken drs. R.J.P. Dekker en student-assistente M.E.C. Reiners voor hun assistentie bij respectievelijk de verzameling en de verwerking van de vele gegevens. 


\section{INLEIDING}

Het Researchcentrum voor Onderwijs en Arbeidsmarkt (ROA) verschaft reeds enkele jaren vanuit het ontwikkelde informatiesysteem onderwijs-arbeidsmarkt informatie over de actuele en toekomstige situatie met betrekking tot de aansluiting tussen onderwijs en arbeidsmarkt. De gegevens hebben daarbij betrekking op 93 beroepsklassen en 49 opleidingstypen, verdeeld over de gehele breedte van de arbeidsmarkt. Deze informatie vindt op twee verschillende manieren zijn weg naar meerdere gebruikers. In de eerste plaats worden de gegevens ingepast in het door het Landelijk Dienstverlenend Centrum voor studie- en beroepskeuzevoorlichting (LDC) ontwikkelde Information-System on education and employment (I-Seel). In de tweede plaats worden de belangrijkste resultaten tweejaarlijks gepubliceerd in het rapport De arbeidsmarkt naar opleiding en beroep (zie ROA, 1992).

Het ROA-informatiesysteem bevat tot op heden voornamelijk landelijke gegevens. Onlangs is echter onderzocht in hoeverre het wenselijk en mogelijk is de verschillende momenteel op landelijk niveau beschikbare arbeidsmarktinformatie te regionaliseren (zie Berendsen, De Grip, Wieling en Willems, 1992a). De informatie heeft daarbij betrekking op actuele data en arbeidsmarktindicatoren en op arbeidsmarktprognoses voor de middellange termijn. De conclusie van dit onderzoek is dat het voor enkele actuele 'kernindicatoren' en de onderliggende actuele arbeidsmarktinformatie zinvol is deze op regionaal niveau weer te geven. Daarnaast leveren de regionale arbeidsmarktprognoses belangrijke additionele informatie op boven de landelijke gegevens. Als regionale invalshoek is in dit verkennende onderzoek het provincieniveau gekozen. Op dit regionale niveau is het mogelijk zowel actuele data en indicatoren als arbeidsmarktprognoses voor de middellange termijn te genereren. Daarnaast is nagegaan of de informatie ook op RBA-niveau zou kunnen worden gepresenteerd. Vooralsnog is het op dit RBAniveau slechts mogelijk om regionale gegevens over de huidige arbeidsmarktsituatie te verstrekken.

Opgemerkt moet worden dat slechts voor de beroepsklassen en opleidingstypen met tenminste 5.000 werkenden in een bepaalde provincie of in een bepaald RBA-gebied arbeidsmarktgegevens kunnen worden gepubliceerd, enerzijds vanwege de betrouwbaarheid van de uitkomsten en anderzijds vanwege de publikatierestricties die het Centraal Bureau voor de Statistiek (CBS) aan de gegevens afkomstig uit de Enquête Beroepsbevolking (EBB) heeft gesteld, om wille van de privacygevoeligheid van in verregaande mate gedetailleerde gegevens. Deze publikatiebeperking impliceert dat voor acht van de twaalf provincies arbeidsmarktinformatie naar beroepsklasse kan worden verstrekt met betrekking tot meer dan $50 \%$ van de totale werkgelegenheid in de desbetreffende provincie. Bij de verbijzondering van de arbeidsmarktgegevens naar opleidingstype zijn het hoger beroepsonderwijs $(H B O)$ en het wetenschappelijk onderwijs (WO), alsmede het (ROA-)opleidingstype 'MBO Politie \& Defensie' buiten beschouwing gebleven, aangezien voor deze opleidingen niet of nauwelijks sprake is van regionaal afgebakende arbeidsmarkten. Voor tien provincies kan voor tenminste de helft van het aantal onderscheiden opleidingstypen regionale informatie worden weergegeven. Voor deze tien provincies is een regionale verbijzondering van de landelijke arbeidsmarktgegevens naar 
opleidingstype van het ROA zinvol. De twee vitzonderingen zijn daarbij de provincies Zeeland en Flevoland. Op het verder verbijzonderde RBA-niveau kan vooralsnog minder informatie worden verstrekt.'. Overigens is het wellicht in de nabije toekomst mogelijk op RBA-niveau voor meer beroepsklassen en opleidingstypen actuele arbeidsmarktinformatie te verstrekken (zie ook Berendsen, De Grip, Wieling en Willems, 1992a).

In dit rapport wordt bij wijze van voorbeeld van de mogelijkheden die de regionalisering van het informatiesysteem onderwijs-arbeidsmarkt van het ROA biedt, de beschikbare arbeidsmarktinformatie voor de provincie Noord-Holland gepresenteerd ${ }^{2}$. Deze provincie neemt wat betreft het aantal te presenteren beroepsklassen en opleidingstypen binnen de provincies waarvoor op zinvolle wijze arbeidsmarktgegevens naar beroepsklasse kunnen worden verstrekt min of meer een middenpositie in. Voor deze provincie kan informatie worden gegeven over in totaal 53 beroepsklassen die te zamen $88 \%$ van de totale werkgelegenheid vertegenwoordigen. Bovendien kunnen gegevens worden verstrekt voor 16 verschillende opleidingstypen.

Behalve dit rapport met specifieke informatie over de provincie Noord-Holland, is voor de provincie Friesland, die samenvalt met een RBA-regio, een tabellenoverzicht samengesteld met de beschikbare regionale arbeidsmarktinformatie (zie Berendsen, De Grip, Wieling en Willems, $1992 b)$.

Het rapport bestaat uit twee delen. In het eerste deel worden de belangrijkste resultaten gepresenteerd en kort toegelicht. Daarbij worden eerst in hoofdstuk 2 enkele actuele arbeidsmarktgegevens besproken. Vervolgens wordt in hoofdstuk 3 ingegaan op de arbeidsmarktprognoses per beroepsklasse en opleidingstype. Het tweede deel bestaat uit een uitgebreid tabellenoverzicht. Daarin zijn tabellen opgenomen van de actuele arbeidsmarktgegevens en de prognoseresultaten die in respectievelijk de hoofdstukken 2 en 3 aan de orde zijn gekomen. Daarnaast worden in dit tabellenoverzicht enkele andere, niet in de hoofdtekst besproken, arbeidsmarktgegevens weergegeven. Bovendien worden in dit overzicht enkele kerngegevens van het informatiesysteem ook voor de vier RBA-gebieden binnen de provincie Noord-Holland gepresenteerd. Het gaat daarbij om de RBA-regio's Gooi en Vechtstreek, NoordHolland Noord, Amsterdam/Zaanstreek/Waterland en Kennemer/Amstel- en Meerlanden. Het tabellenoverzicht is als volgt gestructureerd. Eerst komen enkele provinciespecifieke gegevens aan de orde; daarna wordt ingegaan op de informatie voor de vier onderliggende RBA-gebieden. In beide gevallen is de opzet als volgt. Eerst wordt ingegaan op de leeftijdsstructuur en de conjunctuurgevoeligheid van de totale werkgelegenheid in de diverse regio's. Daarna wordt een beeld geschetst van de bedrijfssectorstructuur. Vervolgens wordt de beroepsspecifieke arbeidsmarktinformatie weergegeven en tenslotte worden de opleidingsspecifieke gegevens gepresenteerd.

1. Zie voor een overzicht van de beschikbaarheid van arbeidsmarktinformatie naar RBAgebied Berendsen, De Grip, Wieling en Willems (1992a).

2. Er wordt derhalve niet ingegaan op de gehanteerde onderzoeksmethodieken. Daarvoor wordt verwezen naar Berendsen, De Grip, Wieling en Willems (1992a). 


\section{ENKELE ACTUELE ARBEIDSMARKTGEGEVENS}

\subsection{Inleiding}

Zoals in hoofdstuk 1 reeds is aangegeven, bestaat het informatiesysteem onderwijsarbeidsmarkt van het ROA zowel uit actuele data en indicatoren met betrekking tot de huidige situatie op de arbeidsmarkt als uit arbeidsmarktprognoses voor de middellange termijn. In dit hoofdstuk wordt op enkele regionale actuele arbeidsmarktdata en -indicatoren nader ingegaan. De gegevens hebben daarbij in het algemeen betrekking op de periode 1988-1990 . Aangezien de EBB pas sinds 1990 betrouwbare opleidingsgegevens op een redelijk gedesaggregeerd niveau bevat, heeft de opleidingeninformatie slechts betrekking op dit laatstgenoemde jaar.

De verdere opzet van het hoofdstuk is als volgt. Eerst wordt in paragraaf 2.2 . ingegaan op de leeftijdsstructuur en de conjunctuurgevoeligheid van de werkgelegenheid in de diverse provincies, waarbij vanzelfsprekend met name de positie van de provincie Noord-Holland wordt besproken. Vervolgens komt in paragraaf 2.3. de sectorstructuur van de werkgelegenheid in de provincie Noord-Holland aan de orde. Het hoofdstuk wordt in paragraaf 2.4. afgesloten met enkele beroeps- en opleidingsgegevens.

\subsection{Leeftijdsstructuur en conjunctuurgevoeligheid}

\section{Leeftijdsstructuur}

Tabel 2.1. geeft een beeld van de leeftijdsverdeling van de werkzame bevolking in de diverse provincies. Deze leeftijdsopbouw kan aan de ene kant worden gezien als een indicator van de absorptie van nieuwkomers op de arbeidsmarkt (zie ook ROA, 1992). Aan de andere kant wordt een indicatie gegeven van de te verwachten uittrede-processen op de provinciale arbeidsmarkt.

In het algemeen zijn er tussen de provincies geen grote verschillen in de leeftijdsstructuur van de werkzame bevolking. Uit de tabel blijkt dat alleen de provincie Flevoland op dit punt een uitzonderingspositie inneemt. In deze 'jonge' provincie is het aandeel van ouderen (vanaf 50 jaar) relatief laag en het aandeel van de 30-39-jarigen relatief hoog. Voor de provincie NoordHolland komt het beeld overeen met de landelijke leeftijdsstructuur van de werkzame bevolking.

3. De RBA-gegevens zijn echter pas vanaf 1989 beschikbaar, zodat voor deze regio's het tweejaarlijks gemiddelde van 1989-1990 wordt weergegeven (zie het tabellenoverzicht). 
Tabel 2.1. Leettijdsopbouw werkzame bevolking per provincie Igemiddelde 1988-1990)

\begin{tabular}{lcccc}
\hline Provincie & $\begin{array}{c}\text { Tot 30 jaar } \\
\%\end{array}$ & $\begin{array}{c}30-39 \text { jaar } \\
\%\end{array}$ & $\begin{array}{c}40-49 \\
\%\end{array}$ & $\begin{array}{c}\text { Vanar } 50 \text { jaar } \\
\%\end{array}$ \\
\hline Groningen & 36 & 26 & 23 & 15 \\
Friesland & 36 & 28 & 23 & 14 \\
Drenthe & 34 & 27 & 23 & 15 \\
Overijssel & 37 & 26 & 22 & 15 \\
Gelderland & 36 & 26 & 22 & 15 \\
Utrecht & 36 & 27 & 22 & 15 \\
Noord-Holland & 35 & 28 & 22 & 15 \\
Zuid-Holland & 35 & 28 & 22 & 15 \\
Zeeland & 34 & 28 & 22 & 16 \\
Noord-Brabant & 36 & 27 & 23 & 14 \\
Limburg & 34 & 28 & 23 & 15 \\
Flevoland & 36 & 32 & 21 & 10 \\
& & & & 15 \\
Totaal & 36 & 27 & 22 & \\
\hline
\end{tabular}

Bron: CBS/ROA

\section{Conjunctuurgevoeligheid}

Met behulp van een conjunctuurindicator kan worden aangegeven in hoeverre er in een bepaalde provincie in het algemeen sprake is van een relatief stabiele, dan wel instabiele werkgelegenheidssituatie. De provinciale conjunctuurindicator wordt daarbij bepaald door de werkgelegenheidsfluctuaties in de diverse bedrijfssectoren in het verleden te relateren aan de huidige sectorstructuur in de verschillende provincies. Bij een hoge waarde van de indicator is er sprake van een relatief hoge conjunctuurgevoeligheid van de werkgelegenheid en derhalve van een meer onzekere situatie op de arbeidsmarkt.

De conjunctuurgevoeligheid van de werkgelegenheid in de verschillende provincies wordt weergegeven in tabel 2.2. Daarbij is tevens met een ' $A$ ' en ' + ' aangegeven of de conjunctuurgevoeligheid respectievelijk relatief laag of relatief hoog is in vergelijking met het landelijke gemiddelde ${ }^{\ddagger}$. De provincie Noord-Holland neemt wat dit betreft een gunstige positie in. De conjunctuurgevoeligheid van de werkgelegenheid is in deze provincie, evenals in de beide andere Randstadprovincies Utrecht en Zuid-Holland, relatief laag. Ook in de provincie Flevoland is sprake van een lage conjunctuurgevoeligheid van de werkgelegenheid. De provincies Overijssel, Noord-Brabant en Limburg worden daarentegen gekenmerkt door een hoge conjunctuurgevoeligheid.

4. Deze typering is toegekend op basis van het gemiddelde en de standaarddeviatie van de gerealiseerde waarden (zie Wieling, De Grip en Willerns, 1990). 
Tabel 2.2. Conjunctuurgevoeligheid per provincie

\begin{tabular}{l} 
Provincie Conjunctuurindicator \\
\hline
\end{tabular}

\begin{tabular}{|c|c|}
\hline Groningen & 1,64 \\
\hline Friesland & 1,67 \\
\hline Drenthe & 1,68 \\
\hline Overijssel & 1,77 \\
\hline Gelderland & 1,70 \\
\hline Utrecht & 1,60 \\
\hline Noord-Holland & 1,60 \\
\hline Zuid-Holland & 1,59 \\
\hline Zeeland & 1,70 \\
\hline Noord-Brabant & 1.84 \\
\hline Limburg & 1,78 \\
\hline Flevoland & 1,48 \\
\hline
\end{tabular}

Bron: ROA

\subsection{Sectorstructuur}

De sectorstructuur van de werkgelegenheid is in belangrijke mate bepalend voor de economische ontwikkeling in een provincie. Bij een goede vertegenwoordiging van de (landelijke) groeisectoren in een bepaalde provincie zal de werkgelegenheidsontwikkeling in deze provincie doorgaans ook gunstig zijn. Als daarentegen de provinciale werkgelegenheid in enkele 'zwakkere' bedrijfssectoren is geconcentreerd, dan zullen de arbeidsmarktontwikkeling in de desbetreffende provincie vanzelfsprekend minder gunstig zijn. De bedrijfssectorstructuur is daarbij niet alleen van invloed op de in de vorige paragraaf gepresenteerde conjunctuurgevoeligheid van de werkgelegenheid, maar is natuurlijk ook van belang voor de beroepen- en de opleidingenstructuur van de werkgelegenheid in deze provincie.

Tabel 2.3. geeft aan hoe in de provincie Noord-Holland de werkgelegenheid over de verschillende bedrijfssectoren is verdeeld. Daarbij is tevens met een ' $\because$ ' of ' $+{ }^{\prime}$ aangegeven hoe de werkgelegenheidsaandelen van de verschillende bedrijfssectoren zich verhouden tot de landelijke sectorale werkgelegenheidsstructuur ${ }^{5}$. In tabel 3 van het tabellenoverzicht wordt bovendien een indicatie gegeven van de recente (trendmatige) ontwikkeling van het aandeel van de diverse sectoren in de totale provinciale werkgelegenheid.

Uit tabel 2.3. blijkt dat de sectorale werkgelegenheidsstructuur in de provincie Noord-Holland slechts in geringe mate afwijkt van de landelijke structuur. Wel vallen enkele kleine verschillen op. In de eerste plaats is de bedrijfssector 'Landbouw, visserij en bosbouw' in Noord-Holland

5. Daarbij wordt ervan uitgegaan dat het provinciale beeld verschillend is van het landelijke beeld bij een afwijking van tenminste $10 \%$ en minimaal 2 procentpunten. 
iets minder goed vertegenwoordigd. Daarentegen werken in deze provincie relatief veel mensen in de sectoren 'Vervoer en communicatie', 'Banken en Verzekeringen' en 'Overige commerciële dienstverlening'. De provincie Noord-Holland wordt derhalve gekenmerkt door een sterke vertegenwoordiging van de tertiaire sector. Het aandeel van de agrarische en van de industriële sector in de totale provinciale werkgelegenheid is daarentegen iets kleiner dan het landelijk gemiddelde.

Tabel 2.3. Aantal werkenden en percentage van de totale werkgelegenheid per bedrijfssector voor de provincie Noord-Holland (gemiddelde 1988-1990)

\begin{tabular}{lll}
\hline Bedriffssector & Aantal & $\%$
\end{tabular}

Landbouw, visserij en bosbouw

Voedings- en genotmiddelenindustrie

Kleding- en schoenenindustrie

Hout- en bouwmaterialenindustrie

Papier-en grafische industrie

Chemie

Metaalindustrie

Elektrotechnische industrie

Transportmiddelenindustrie

Energie

Bouw

Handel

Vervoer en communicatie

Banken en verzekeringen

Horeca

Overige commerciele dienstverlening

Gezondheidszorg

Maatschappelijke dienstverlening

Openbaar bestuur, politie en defensie

Onderwijs

Totaal (incl. woningbezit en bedrijfssector onbekend)

$+\quad=$ relatief hoog ten opzichte van het landelijk gemiddelde

= relatief laag ten opzichte van het landelijk gemiddelde

$\begin{array}{rrr}31.000 & 3 & (-) \\ 20.000 & 2 & \\ 6.000 & 1 & \\ 7.000 & 1 & \\ 33.000 & 3 & \\ 17.000 & 2 & \\ 46.000 & 4 & \\ 12.000 & 1 & \\ 9.000 & 1 & \\ 9.000 & 1 & \\ 53.000 & 5 & \\ 164.000 & 16 & \\ 79.000 & 8 & 1+1 \\ 53.000 & 5 & 1+1 \\ 33.000 & 3 & \\ 135.000 & 13 & 1+1 \\ 83.000 & 8 & \\ 104.000 & 10 & \\ 86.000 & 8 & \\ 64.000 & 6 & \\ & & \\ 1.050 .000 & 100 & \end{array}$

Bron: CBS/ROA

\subsection{Beroeps- en opleidingsgegevens}

Aantal werkenden en percentage van de totale werkgelegenheid per beroepsklasse

Tabel 2.4. geeft voor de tien grootste beroepsklassen in de provincie Noord-Holland het gemiddeld aantal werkenden in de periode 1988-1990. Het blijkt dat de werkgelegenheid vooral is geconcentreerd in enkele economisch-administratieve beroepen ${ }^{6}$. Met gemiddeld 72.000 werkenden is de beroepsklasse 'Boekhoudkundige, belasting-, loket- en bankemployees' het

6. Dit zijn de ROA-beroepsklassen met als eerste digit 6 . 
grootste. Het aandeel van de diverse beroepsklassen in de totale werkgelegenheid komt ongeveer overeen met het landelijk gemiddelde.

In het uitgebreide tabellenoverzicht van dit rapport wordt het aantal werkenden voor alle beroepsklassen waarin tenminste 5.000 personen werkzaam zijn weergegeven. Daarnaast wordt in deze bijlage een overzicht gegeven van de 'belangrijkste opleidingstypen' en de 'belangrijkste bedrijfssectoren' van de verschillende beroepsklassen (zie respectievelijk tabel 5 en 6 van het tabellenoverzicht). Ook hiervoor geldt overigens dat het provinciale beeld slechts weinig afwijkt van het landelijke beeld.

Tabel 2.4. Beroepsklassen met het hoogste aantal werkenden in de provincie Noord-Holland (gemiddelde 1988-1990)

ROA- Beroepsklasse

code
Aantal $\%$

$\begin{array}{ll}72.000 & 7 \\ 69.000 & 7 \\ 61.000 & 6 \\ 57.000 & 5 \\ 41.000 & 4 \\ 31.000 & 3 \\ 29.000 & 3 \\ 29.000 & 3 \\ 27.000 & 3 \\ 25.000 & 2\end{array}$

\section{7}

5

4

3

3

2
6124 Boekhoudkundige, belasting-, loket- en bankemployees

6211 Winkel-, straat- en marktverkopers, demonstrateurs

6125 Commercieel-administratieve employees

3021 Directeuren, bedrijfsleiders, leidinggevenden industrie

8211 Portiers, schoonmaak- e.a. lager dienstverlenend personeel

6122 Secretaressen, typisten

0132 Docenten voortgezet en hoger anderwijs

8111 Koks, kelners e.a. keuken- en serveerpersoneel

8212 Kinder-, gezins-, bejaardenverzorgenden e.a. verzorgend personeel

6221 Winkeliers e.a. detail- en groothandelaren

Bron: CBS/ROA

\section{Aantal werkenden en percentage van de totale werkgelegenheid per opleidingstype}

Zoals reeds eerder is aangegeven, blijven bij de regionalisering van de opleidingsgegevens de WO- en HBO-opleidingen, alsmede het opleidingstype 'MBO Politie \& Defensie' buiten beschouwing. Voor deze opleidingen is er immers niet of nauwelijks sprake van regionaal afgebakende arbeidsmarkten. $\mathrm{Na}$ een verdere selectie op opleidingstypen met tenminste 5.000 werkenden, resteren 16 opleidingstypen waarvoor arbeidsmarktinformatie voor de provincie Noord-Holland kan worden gepresenteerd. Het aantal werkenden en het percentage van de totale provinciale werkgelegenheid wordt voor deze opleidingstypen weergegeven in tabel 2.5 .

Van de geselecteerde opleidingstypen heeft 'MBO Economisch \& Administratief met 120.000 personen het grootste aantal werkenden in de provincie Noord-Holland. Bovendien zijn er in deze provincie meer dan 100.000 werkenden met als opleidingsachtergrond 'Basisonderwijs' (de 'drop-outs' van het voortgezet onderwijs) en 'MBO Technisch'. Het aandeel van 'LBO Technisch' in de totale werkgelegenheid is voor Noord-Holland lager dan het landelijk gemiddelde. Daarentegen heeft een relatief groot deel van de werkenden 'Boveribouw HAVO/VWO' als opleidingsachtergrond. In het tabellenoverzicht wordt nader ingegaan op de 'belangrijkste beroepsklassen' en de 'belangrijkste bedrijfssectoren' van de onderscheiden 
opleidingstypen waarin degenen met een bepaalde opleidingsachtergrond werkzaam zijn (zie daarvoor respectievelijk tabel 11 en 12 van het tabellenoverzicht).

Tabel 2.5. Aantal werkenden en percentage van de totale werkgelegenheid per opleidingstype voor de provincie Noord-Holland 1990

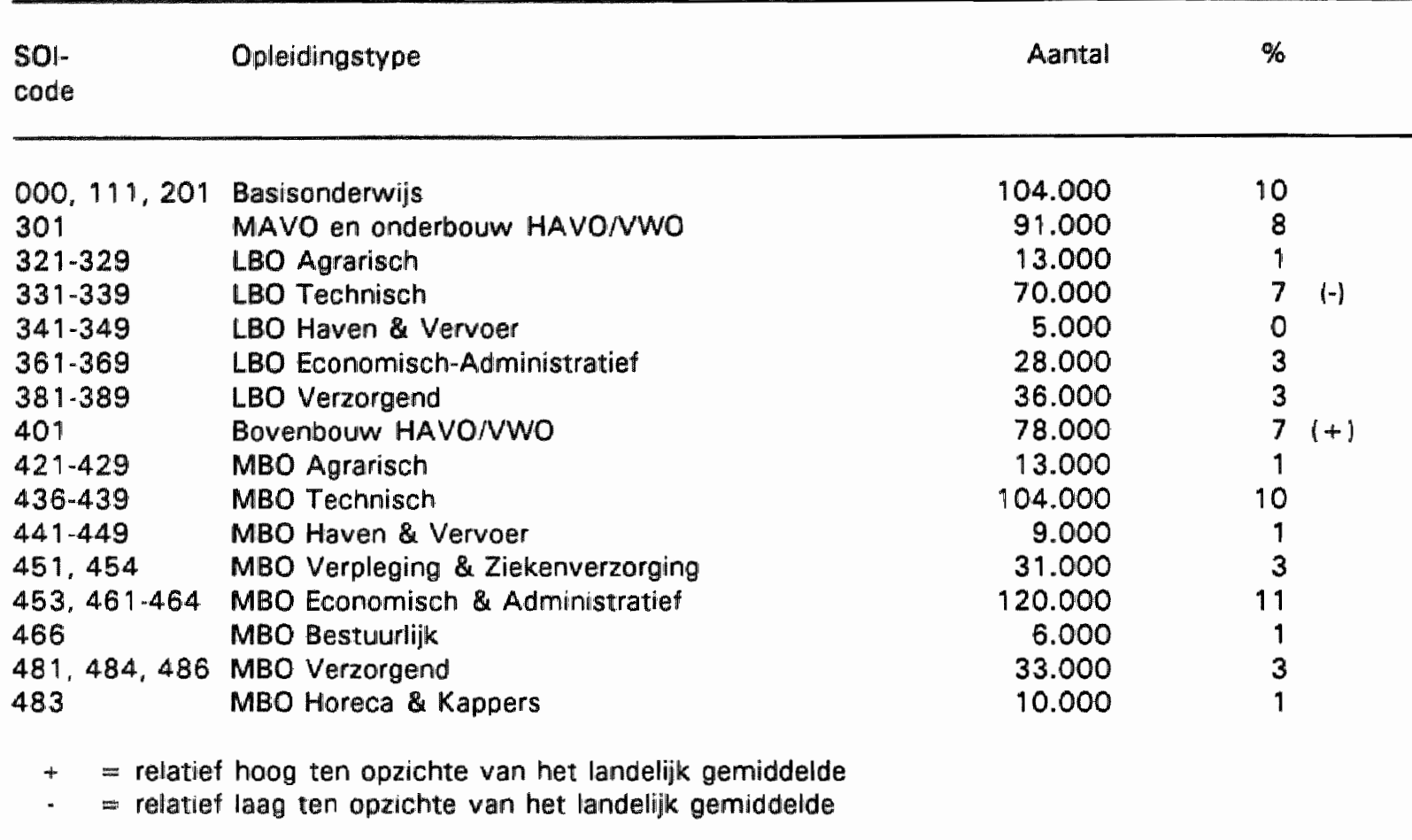

Bran: CBS/ROA

Werkloosheid per opleidingstype

In tabel 2.6. wordt voor de geselecteerde opleidingstypen het werkloosheidspercentage ${ }^{7}$ in april 1991 weergegeven. Het blijkt dat de provincie Noord-Holland wat dit betreft een ongunstige positie inneemt. Met name voor de ('algemene') opleidingstypen 'Basisonderwijs' , 'MAVO en onderbouw HAVO/VWO' en 'Bovenbouw HAVO/VWO', en voor enkele opleidingstypen op LBOniveau is de werkloosheid hoger dan het landelijke gemiddelde. Voor deze opleidingstypen kan de provinciale werkloosheid als (erg) hoog worden getypeerd.

De onderscheiden MBO-opleidingstypen worden vrijwel allemaal gekenmerkt door een (erg) lage werkloosheid. Een uitzondering wordt daarbij gevormd door het opleidingstype "MBO

7. Evenals in het landelijke informatiesysteem wordt daarbij het werkloosheidspercentage verkregen door de werkloosheid in 1991 te relateren aan de som van het aantal werkenden in 1990 en de werkloosheid in 1991. Er is daarbij gebruik gemaakt van de ISVA-bestanden van de Arbeidsvoorzieningsorganisatie, waarvan algemeen bekend is dat deze gegevens onnauwkeurig zijn, vanwege de bestandsvervuiling en de enigszins tekortschietende codering van de opleidingsgegevens. Voor het onderling vergelijken van werkloosheidscijfers is het ISVA-bestand ons inziens echter een waardevolle informatiebron. 
Verzorgend', waar de werkloosheid ongeveer gelijk is aan het landelijk gemiddelde voor alle opleidingstypen. Voor alle gepresenteerde MBO-opleidingen wijkt de provinciale werkloosheid niet of nauwelijks af van het landelijke beeld.

Tabel 2.6. Werkloosheidspercentage per opleidingstype voor de provincie Noord-Holland april 1991 (berniddelingsbestand zonder baan)

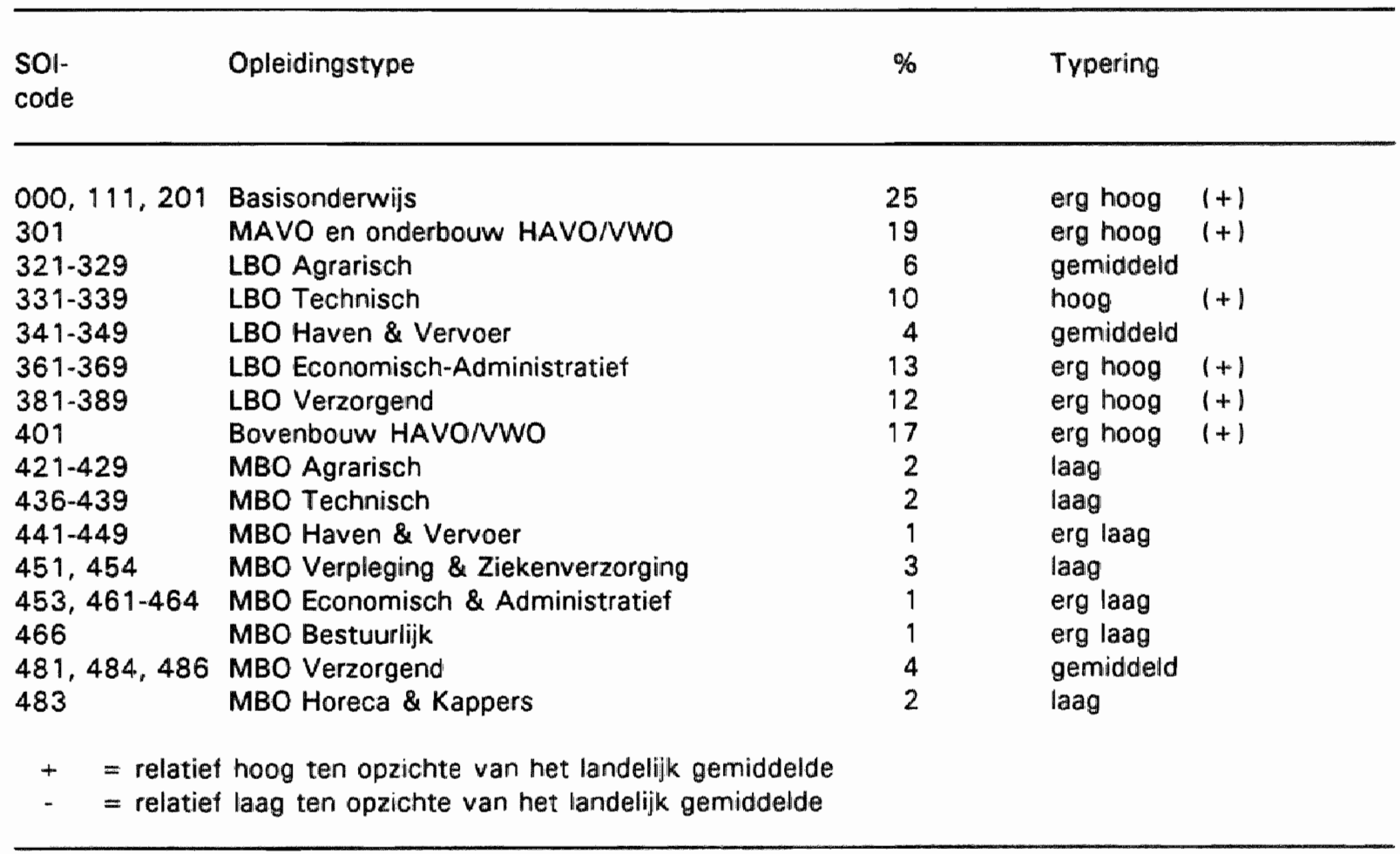

Bron: Arbeidsvoorzieningsorganisatie/ROA

\section{Bedrijfssectorspreiding per opleidingstype}

De bedrijfssectorspreiding per opleidingstype geeft een indicatie van de flexibiliteit van de verschillende opleidingscategorieën op de arbeidsmarkt. Een hoge spreiding duidt daarbij op relatief veel uitwijkmogelijkheden en dus een minder kwetsbare positie op de arbeidsmarkt (zie bijvoorbeeld ook De Grip, Van der Velden en Wieling, 19911. In tabel 2.7. wordt voor de geselecteerde opleidingstypen de bedrijfssectorspreiding weergegeven.

Voor de meeste van de in deze tabel gepresenteerde opleidingstypen is de sectorspreiding gemiddeld of hoog. Een uitzondering hierop wordt gevormd door de opleidingstypen "MBO Verzorgend' en 'MBO Bestuurlijk'. De werkenden met deze opleidingsachtergrond komen in relatief weinig sectoren terecht. Tot slot kan worden opgemerkt dat voor vrijwel alle opleidingstypen het provinciale beeld min of meer overeenkomt met de landelijke resultaten. 
Tabel 2.7. Bedrijfssectorspreiding per opleidingstype woor de provincie Noord-Holland 1990 IGiniHirschman indicator)

\begin{tabular}{|c|c|c|}
\hline $\begin{array}{l}\text { SOl- } \\
\text { code }\end{array}$ & Opleidingstype & $\begin{array}{l}\text { Gini-Hirschman } \\
\text { indicator }\end{array}$ \\
\hline
\end{tabular}

$\begin{array}{ll}000,111,201 & \text { Basisonderwijs } \\ 301 & \text { MAVO en onderbouw HAVO/NWO } \\ 321-329 & \text { LBO Agrarisch } \\ 331-339 & \text { LBO Technisch } \\ 341-349 & \text { LBO Haven \& Vervoer } \\ 361-369 & \text { LBO Economisch-Administratief } \\ 381-389 & \text { LBO Verzorgend } \\ 401 & \text { Bovenbouw HAVO/NWO } \\ 421-429 & \text { MBO Agrarisch } \\ 436-439 & \text { MBO Technisch } \\ 441-449 & \text { MBO Haven \& Vervoer } \\ 451,454 & \text { MBO Verpleging \& Ziekenverzorging } \\ 453,461-464 & \text { MBO Economisch \& Administratief } \\ 466 & \text { MBO Bestuurlijk } \\ 481,484,486 & \text { MBO Verzorgend } \\ 483 & \text { MBO Horeca \& Kappers }\end{array}$
0,95
0,94
0,78
0,93
0.76
0,90
0,91
0,94
0,79
0,94
0,82
0,52
0,92
0,54
0,85
0,84
groot
groot
gemiddeld
groot
gemiddeld
groot
groot
groot
gemiddeld
groot
gemiddeld
erg klein
groot
erg klein
gemiddeld
gemiddeld

Bron: CBS/ROA 


\section{STROMEN OP DE ARBEIDSMARKT}

\subsection{Inleiding}

Bij het opstellen van de arbeidsmarktprognoses in het ROA-informatiesysteem onderwijsarbeidsmarkt is gekozen voor een 'stroomcijfer' aanpak. Dit betekent dat de prognoses niet betrekking hebben op een bepaald toekomstig tijdstip maar op een bepaalde toekomstige periode. Momenteel hebben de prognoses betrekking op de periode 1989-1994. Deze aanpak maakt het mogelijk de diverse onderliggende factoren van vraag en aanbod op inzichtelijke wijze in beeld te brengen (zie ook figuur 3.1.). Daarbij wordt aan de vraagzijde van de arbeidsmarkt een onderscheid gemaakt tussen aan de ene kant de verwachte uitbreidingsvraag op grond van de werkgelegenheidsontwikkeling voor een bepaalde beroepsklasse of een bepaald opleidingstype en aan de andere kant de verwachte vervangingsvraag vanwege pensionering, (tijdelijke) terugtreding van de arbeidsmarkt, beroepsmobiliteit e.d. De uitbreidingsvraag en de vervangingsvraag vormen samen de verwachte baanopeningen. Aan de aanbodzijde van de arbeidsmarkt worden de toekomstige instroom van schoolverlaters en het aanbod van (kortdurig) werklozen onderscheiden. Door de verwachte vraag- en aanbodstromen met elkaar te confronteren, kan een typering van de toekomstige arbeidsmarktsituatie per opleidingstype worden gegeven.

In het vervolg van dit hoofdstuk wordt nader op de bovengenoemde stromen op de arbeidsmarkt ingegaan. Bij de beroepsklasseprognoses wordt alleen een beeld geschetst van de tien beroepsklassen met de grootste en kleinste verwachte uitbreidingsvraag en vervangingsvraag en de tien beroepsklassen met naar verwachting het grootste en het kleinste aantal baanopeningen ${ }^{2}$. De resultaten voor de verschillende opleidingstypen worden daarentegen steeds integraal weergegeven. Voor de goede orde moet daarbij nogmaals worden opgemerkt dat alleen informatie wordt gegeven over beroepsklassen en opleidingstypen met tenminste 5.000 werkenden in de provincie Noord-Holland. Bovendien zijn, zoals gezegd, de HBO- en WO-opleidingen, alsmede het opleidingstype 'MBO Politie \& Defensie' buiten beschouwing gebleven. Bij de interpretatie van de prognoseresultaten moet hiermee vanzelfsprekend rekening worden gehouden.

De verdere opzet van dit hoofdstuk is als volgt. Eerst komt in paragraaf 3.2. de verwachte uitbreidingsvraag per beroepsklasse en opleidingstype aan de orde. Daarna wordt in paragraaf 3.3. ingegaan op de vervangingsvraag. Vervolgens worden in paragraaf 3.4. de prognoseresultaten van de toekomstige baanopeningen gepresenteerd. Paragraaf 3.5 . behandelt de verwachte instroom van schoolverlaters op de arbeidsmarkt. Het hoofdstuk wordt in paragraaf 3.6. afgesloten met de typering van de toekomstige arbeidsmarktperspectieven per opleidingstype.

8. Voor een totaalbeeld naar beroepsklasse wordt verwezen naar het tabellenoverzicht. 
Figuur 3.1. Stromen op de arbeidsmarkt

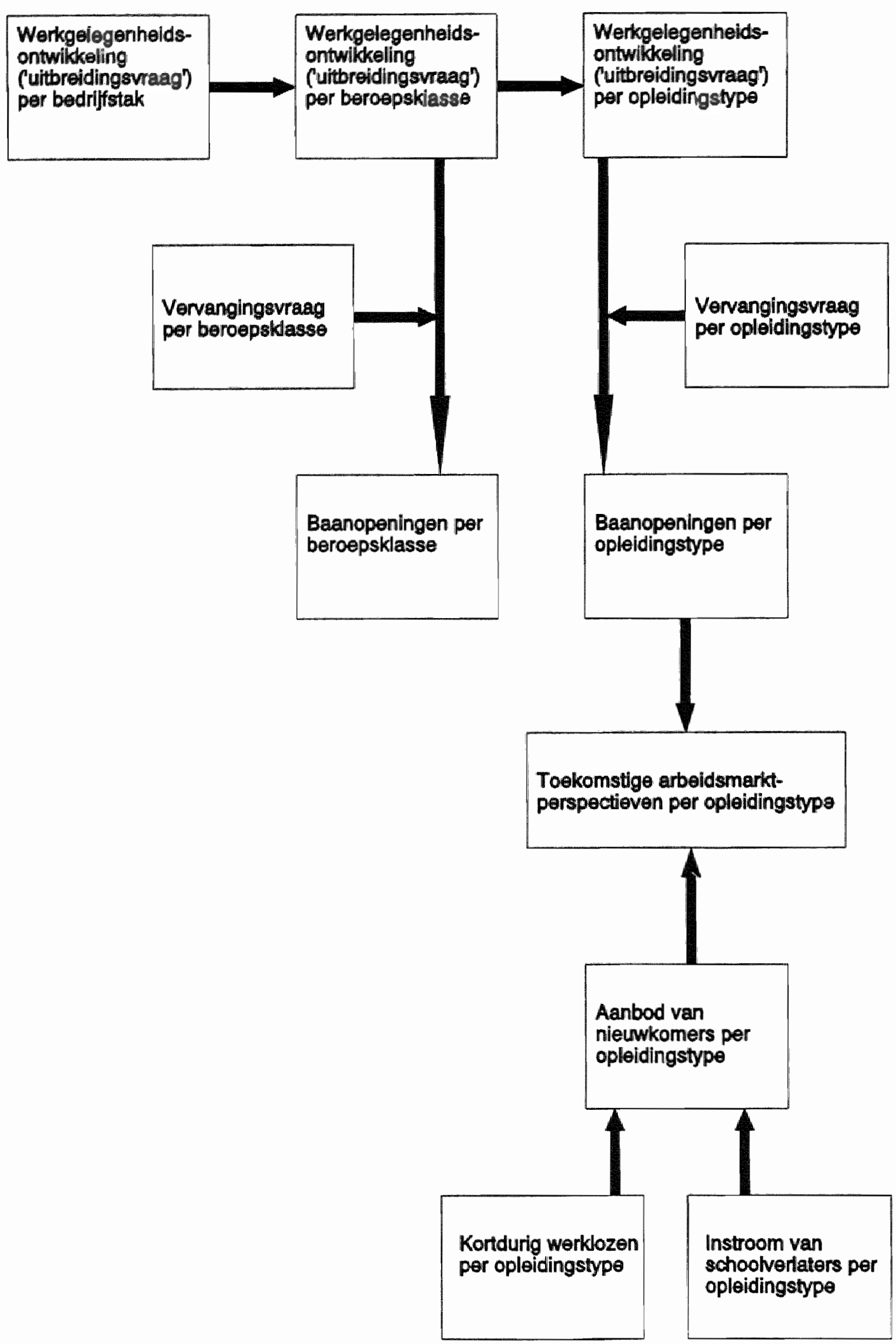




\subsection{Uitbreidingsvraag}

\section{Beroepen}

Tabel 3.1. geeft een overzicht van de tien beroepsklassen met naar verwachting de grootste werkgelegenheidsgroei in de periode 1989-1994. In het bovenste deel van de tabel staan de beroepsklassen met abso/uut gezien de grootste groei en in het onderste deel de beroepsklassen met de relatief grootste werkgelegenheidsgroei. Bovendien is met ' $"$ ' en ' +' aangegeven of het uitbreidingsvraagpercentage van een bepaalde beroepsklasse voor de provincie Noord-Holland lager dan wel hoger is dan het landelijk gemiddelde voor de desbetreffende beroepsklasse ${ }^{a}$.

Voor de beroepsklassen waarin veel mensen werkzaam zijn, geldt vanzelfsprekend dat een kleine procentuele werkgelegenheidsgroei reeds voldoende is om in de lijst van beroepsklassen met een absoluut gezien hoge uitbreidingsvraag terecht te komen. Omgekeerd geldt dat de 'kleine' beroepsklassen doorgaans een lage absolute uitbreidingsvraag zullen hebben. De absolute rangordening geeft echter een duidelijk inzicht in het belang van de diverse beroepsklassen voor de totale werkgelegenheidsgroei in de provincie. De relatieve rangordening geeft daarentegen een beter inzicht in de relatieve verschillen in de verwachte uitbreidingsvraag.

De totale werkgelegenheidsgroei in de provincie Noord-Holland in de periode 1989-1994 bedraagt naar verwachting 71.100 personen. Dit komt overeen met $7 \%$ van het aantal werkenden in 1989. Ter vergelijking: de totale Nederlandse werkgelegenheid neemt in deze periode naar verwachting eveneens met $7 \%$ toe.

De absoluut gezien hoogste uitbreidingsvraag wordt verwacht voor de beroepsklasse 'Directeuren, bedrijfsleiders, leidinggevenden industrie'. Ook landelijk gezien is voor deze beroepsklasse de verwachte absolute uitbreidingsvraag het hoogst. In relatieve zin is de toekomstige uitbreidingsvraag naar verwachting het hoogst voor de beroepsklasse 'Auteurs, journalisten, nieuwslezers en presentatoren', Ook dit stemt overeen met het landelijke beeld. Voor vrijwel alle gepresenteerde beroepsklassen wijkt het provinciale beeld niet of nauwelijks af van de landelijk verwachte uitbreidingsvraagpercentages. Een uitzondering wordt daarbij gevormd door de beroepsklasse 'Politie-, brandweer- en bewakingspersoneel', waarvoor de procentuele uitbreidingsvraag naar verwachting groter is dan het landelijk gemiddelde voor deze beroepsklasse.

9. Daarbij worden enige marges aangehouden: als het provinciale uitbreidingsvraagpercentage minder dan $10 \%$ afwijkt van het landelijke percentage of minder dan 2 procentpunten van dit landelijke gemiddelde verschilt, wordt dit als 'min of meer in overeenstemming' met het landelijke percentage beschouwd. 
Tabel 3.1. Beroepsklassen met de hoogste uitbreidingsvraag in de provincie Noord-Holland 1989-1994 (absolute aantallen en als percentage van het aantal werkenden in 1989)

ROA- Beroepsklasse

Aantal

$\%$

code

Absoluut

3021 Directeuren, bedrijfsleiders, leidinggevenden industrie

17.400

31

6211 Winkel-, straat- en marktverkopers, demonstrateurs

13.100

21

6031 Hogere leidinggevenden

8.400

56

8212 Kinder-, gezins", bejaardenverzorgenden e.a. verzorgend personeel

7.600

28

8211 Portiers, schoonmaak- e.a. lager dienstverlenend personeel

7.100

19

7021 Auteurs, journalisten, nieuwslezers, presentatoren

5.900

59

3031 Beta-onderzoekers, technische vakspecialisten

5.100

51

6131 Systeemanalisten, -programmeurs en -beheerders

4211 Conducteurs, chauffeurs e.a. transportmiddelenbestuurders

4.300

21

9121 Politie-, brandweer- en bewakingspersoneel

3.900

15

3.500

$27(+1$

\section{Relatief}

7021 Auteurs, journalisten, nieuwslezers, presentatoren

6031 Hogere leidinggevenden

5.900

8.400

5.100

1.900

17.400

7.600

3.500

13.100

4.300

1.500

3021 Directeuren, bedrijfsleiders, leidinggevenden industrie

8212 Kinder-, gezins-, bejaardenverzorgenden e.a. verzorgend personeel

6211 Winkel-, straat- en marktverkopers, demonstrateurs

6131 Systeemanalisten, -programmeurs en -beheerders

6332 Juristen

+ = relatief hoog ten opzichte van het landelijk gemiddelde

= relatief laag ten opzichte van het landelijk gemiddelde

Bron: ROA

In tabel 3.2. worden de tien beroepsklassen met de naar verwachting grootste werkgelegenheidsdaling gepresenteerd. Absoluut gezien is de daling van de werkgelegenheid naar verwachting het grootst voor de beroepsklasse 'Uitvoerend agrarisch personeel, bosarbeiders'. Voor de beroepsklasse 'Auto-, motor- en bromfietsmonteurs' wordt de grootste relatieve werkgelegenheidsdaling verwacht. De daling bedraagt hier $29 \%$ van het aantal werkenden in 1989, hetgeen overeenkomt met het landelijk verwachte beeld. Verder is het opvallend dat de grootste krimpberoepen uitsluitend bestaan uit agrarische en technische, ambachts- en industrieberoepen. Tenslotte kan worden opgemerkt dat voor de beroepsklasse 'Houtbewerkers, timmerlieden' de verwachte uitbreidingsvraag in de provincie Noord-Holland iets hoger is dan de landelijke prognose, terwijl voor de beroepsklassen 'Onderhoudsmonteurs, fietsen- en instrumentmakers', 'Drukkers, boekbinders, fotolaboranten' en 'Machinebank- en plaatwerkers, gereedschaps- en modelmakers' de werkgelegenheidsontwikkeling in deze provincie achterblijft bij het landelijk gezien al niet rooskleurige beeld. 
Tabel 3.2. Beroepsklassen met de laagste uitbreidingsvraag in de provincie Noord-Holland 1989-1994 (absolute aantallen en als percentage van het aantal werkenden in 1989)

ROA- Beroepsklasse

Aantal

$\%$

code

\section{Absoluut}

2011 Uitvoerend agrarisch personeel, bosarbeiders

$-2.800 \quad-14$

3915 Overige bouwvaklieden, (spoor)weg-en reinigingswerkers

$-2.500$

3312 Houtbewerkers, timmerlieden

$-2.300$

$-141+1$

3615 Onderhoudsmonteurs, fietsen- en instrumentmakers

$-1.900$

$-15 \quad(-)$

2012 Zelfstandige agrariërs, boswachters

$-1.900$

$-14$

3621 Auto-, motor- en bromfietsmonteurs

3914 Loodgieters, sanitair-installateurs en -reparateurs

$-1.700$

$-29$

3411 Drukkers, boekbinders, fotolaboranten

$-1.700$

3614 Machinebank- en plaatwerkers, gereedschaps- en modelmakers

$-1.600$

$-14(-)$

3913 Huis-, scheeps- en constructieschilders

Relatief

3621 Auto-, motor- en bromfietsmonteurs

$-1.700 \quad-29$

3915 Overige bouwvaklieden, (spoor)weg- en reinigingswerkers

$-2.500$

3914 Loodgieters, sanitair-installateurs en -reparateurs

$-1.700$

3913 Huis-, scheeps- en constructieschilders

$-1.200$

3911 Metselaars, tegelzetters, straatmakers, stukadoors

$-1.100$

3615 Onderhoudsmonteurs, fietsen- en instrumentmakers

$-1.900$

$-15$

3613 Lassers, constructiewerkers, edelmetaalsmeden

$-1.200$

2011 Uitvoerend agrarisch personeel, bosarbeiders

$-2.800$

$-15$

3312 Houtbewerkers, timmerlieden

$-2.300$

$-14$

2012 Zelfstandige agrariërs, boswachters

$-1.900$

$-14(+)$

.14

$+\quad=$ relatief hoog ten opzichte van het landelijk gemiddelde

- $=$ relatief laag ten opzichte van het landelijk gemiddelde

Bron: ROA

\section{Opleidingen}

Tabel 3.3. geeft een beeld van de verwachte uitbreidingsvraag per opleidingstype. Zoals reeds eerder is opgemerkt, blijven in dit onderzoek de HBO- en WO-opleidingen, het opleidingstype 'MBO Politie \& Defensie' en de opleidingstypen met minder dan 5.000 werkenden in de provincie Noord-Holland buiten beschouwing. Er is in de tabel daarom geen rangordening naar hoogste of laagste uitbreidingsvraag aangebracht. In plaats daarvan worden in eén tabel alle 16 onderscheiden opleidingstypen gepresenteerd.

Van de geselecteerde opleidingstypen wordt voor 'MBO Economisch \& Administratief' de absoluut gezien hoogste uitbreidingsvraag verwacht. In relatieve zin is de uitbreidingsvraag naar verwachting het grootste voor het opleidingstype 'MBO Verzorgend'. Voor ongeschoolden (opleidingstype 'Basisonderwijs') wordt daarentegen een grote werkgelegenheidsdaling verwacht. Het opleidingstype 'MBO Agrarisch' staat er echter relatief gezien nog slechter voor. Tenslotte kan worden opgemerkt dat, met uitzondering van het opleidingstype 'LBO Agrarisch', 
het verwachte beeld van de werkgelegenheidsontwikkeling per opleidingstype min of meer overeenkomt met de landelijke prognoseresultaten.

Tabel 3.3. Uitbreidingsvraag per opleidingstype voor de provincie Noord-Holland 1989-1994 labsolute aantallen en als percentage van het aantal werkenden in 1989 ,

\begin{tabular}{llrr}
$\begin{array}{l}\text { SOI- } \\
\text { code }\end{array}$ & Opleidingstype & Aantal & $\%$ \\
& & & \\
\hline $000,111,201$ & Basisonderwijs & -11.400 & -11 \\
301 & MAVO en onderbouw HAVONWW & 700 & 1 \\
$321-329$ & LBO Agrarisch & 0 & 0 \\
$331-339$ & LBO Technisch & -4.000 & -6 \\
$341-349$ & LBO Haven \& Vervoer & 1.000 & 19 \\
$361-369$ & LBO Economisch-Administratief & 1.700 & 6 \\
$381-389$ & LBO Verzorgend & 6.100 & 17 \\
401 & Bovenbouw HAVO/NWO & 2.100 & 3 \\
$421-429$ & MBO Agrarisch & -1.600 & -13 \\
$436-439$ & MBO Technisch & 7.600 & 7 \\
$441-449$ & MBO Haven \& Vervoer & 900 & 10 \\
451,454 & MBO Verpleging \& Ziekenverzorging & 3.900 & 13 \\
$453,461-464$ & MBO Economisch \& Administratief & 19.100 & 16 \\
466 & MBO Bestuurlijk & 800 & 14 \\
$481,484,486$ & MBO Verzorgend & 10.200 & 31 \\
483 & MBO Horeca \& Kappers & 100 & 1 \\
$+\quad=$ relatief hoog ten opzichte van het landelijk gemiddelde & & \\
$-\quad=$ relatief laag ten opzichte van het landelijk gemiddelde & &
\end{tabular}

Bron: ROA

\subsection{Vervangingsvraag}

\section{Beroepen}

Naast de uitbreidingsvraag speelt ook de vervangingsvraag als gevolg van pensionering, beroepsmobiliteit e.d. een belangrijke rol in de totale vraag naar nieuwkomers op de arbeidsmarkt. In tabel 3.4, worden de tien beroepsklassen met absoluut en relatief gezien de hoogste vervangingsvraag gepresenteerd. De gemiddelde verwachte vervangingsvraag in de provincie Noord-Holland is $12 \%$ van het aantal werkenden, hetgeen overeenkomt met het landelijke beeld.

De in absolute zin grootste vervangingsvraag wordt, in overeenstemming met de landelijke prognose, verwacht voor de beroepsklasse "Winkel-, straat- en marktverkopers, demonstrateurs'. Voor de beroepsklasse 'Beeldende en vitvoerende kunstenaars' is de relatieve 
vervangingsvraag naar verwachting het hoogst ${ }^{10}$. Voor deze beroepsklasse is de verwachte vervangingsvraag hoog ten opzichte van het landelijke gemiddelde. Ook voor de beroepsklassen 'Drukkers, boekbinders, fotolaboranten', 'Geneeskundigen, medische adviseurs, apothekers' en 'Onderhoudsmonteurs, fietsen- en instrumentmakers' is de procentuele vervangingsvraag in de provincie Noord-Holland naar verwachting hoger dan het landelijk gemiddelde voor de desbetreffende beroepsklassen.

Tabel 3.4. Beroepsklassen met de hoogste vervangingsvraag in de provincie Noord-Holland 1989-1994 (absolute aantallen en als percentage van het aantal werkenden in 1989)

code

\section{Absoluut}

6211 Winkel-, straat- en marktverkopers, demonstrateurs

6125 Commercieel-administratieve employees

6124 Boekhoudkundige, belasting-, loket- en bankemployees

8211 Portiers, schoonmaak- e.a. lager dienstverlenend personeel

3021 Directeuren, bedrijfsleiders, leidinggevenden industrie

8111 Koks, kelners e.a. keuken- en serveerpersoneel

6122 Secretaressen, typisten

4211 Conducteurs, chauffeurs e.a. transportmiddelenbestuurders

5022 Leerling-verpleegkundigen, zieken- en kraamverzorgenden

1331 Beeldende en uitvoerende kunstenaars

$\begin{array}{rr}11.500 & 18 \\ 7.500 & 12 \\ 7.500 & 10 \\ 4.400 & 12 \\ 4.300 & 8 \\ 4.100 & 14 \\ 3.800 & 12 \\ 3.600 & 13 \\ 3.500 & 22 \\ 2.900 & 24 \quad 1+1\end{array}$

\section{Relatief}

1331 Beeldende en uitvoerende kunstenaars

2.900

24. $1+1$

5022 Leerling-verpleegkundigen, zieken- en kraamverzorgenden

3.500

22

11.500

2.000

1.600

900

7021 Auteurs, journalisten, nieuwslezers, presentatoren

5033 Geneeskundigen, medische adviseurs, apothekers

4011 Laders, lossers, vul- en inpak(machıne)bedienden

2.800

2.600

1.900

4.100

18

$181+1$

16

$16(+1$

15

15

$151+1$

3615 Onderhoudsmonteurs, fietsen- en instrumentmake
8111 Kolks, kelners e.a. keuken- en serveerpersoneel

$+\quad=$ relatief hoog ten opzichte van het landelijk gemiddelde

- = relatief laag ten opzichte van het landelijk gemiddelde

Bron: ROA

Tabel 3.5. geeft een overzicht van de tien beroepsklassen met de relatief gezien laagste verwachte vervangingsvraag. Het is niet zinvol de beroepsklassen met de absoluut gezien laagste vervangingsvraag weer te geven, aangezien een groot aantal kleine beroepsklassen (met

10. Landelijk gezien wordt voor de beroepsklasse 'Personeels- en beroepenspecialisten, arbeidsbemiddelaars' het grootste vervangingsvraagpercentage verwacht. Aangezien echter in de provincie Noord-Holland minder dan 5.000 personen in deze beroepsklasse werkzaam zijn, is deze beroepsklasse niet in tabel 3.4. opgenomen. 
minder dan 5.000 werkenden in 19891 niet in het onderzoek is betrokken. De beroepsklassen 'Huis-, scheeps- en constructieschilders' en 'Loodgieters, sanitair-installateurs en -reparateurs' hebben naar verwachting de laagste relatieve vervangingsvraag. Voor de laatstgenoemde beroepsklasse is de vervangingsvraag daarbij duidelijk lager dan het landelijk gemiddelde. Dit is ook het geval bij de beroepsklassen 'Machinisten bouw en industrie', 'Administratief leidinggevenden' en 'Technische tekenaars'.

Tabel 3.5. Beroepsklassen met de laagste vervangingsvraag in de provincie Noord-Holland 1989-1994 (absolute aantallen en als percentage van het aantal werkenden in 1989)

ROA- Beroepsklasse

Aantal

$\%$

code

Relatief

3913 Huis-, scheeps- en constructieschilders

$100 \quad 2$

3914 Loodgieters, sanitair-installateurs en -reparateurs

100

$2(-1$

3012 Machinisten bouw en industrie

200

6121 Administratief leidinggevenden

200

3915 Overige bouwvaklieden, (spoor)weg- en reinigingswerkers

400

3023 Technische tekenaars

300

9121 Politie-, brandweer- en bewakingspersoneel

700

700

7033 Maatschappelijk werkers, reclasseringsambtenaren

3911 Metselaars, tegelzetters, straatmakers, stukadoors

300

6332 Juristen

500

$(-1)$

$+\quad=$ relatief hoog ten opzichte van het landelijk gemiddelde

- = relatief laag ten opzichte van het landelijk gemiddelde

Bron: ROA

\section{Opleidingen}

De vervangingsvraag voor de onderscheiden opleidingstypen is weergegeven in tabel 3.6. Daarbij moet worden gewezen op een belangrijk verschil dat zich voordoet tussen de vervangingsvraag per beroepsklasse en de vervangingsvraag per opleidingstype, namelijk dat de beroepsmobiliteit niet van invloed is op de vervangingsvraag per opleidingstype. Gemiddeld gezien is de vervangingsvraag per opleidingstype derhalve lager dan de vervangingsvraag per beroepsklasse (zie ook Willems en De Grip, 1990).

Van de onderscheiden opleidingstypen heeft 'MAVO en onderbouw HAVONWO' naar verwachting de grootste absolute vervangingsvraag. Relatief gezien wordt voor het opleidingstype 'MBO Haven \& Vervoer' de grootste vervangingsvraag verwacht. Voor de opleidingstypen 'LBO Agrarisch', 'LBO Economisch-Administratief' en 'LBO Verzorgend' is het verwachte vervangingsvraagpercentage lager dan de landelijke vervangingsvraag voor deze opleidingstypen. Voor het opleidingstype 'MBO Bestuurlijk' wordt daarentegen een vervangingsvraag verwacht die hoger is dan de landelijke prognose. 
Tabel 3.6. Vervangingsvraag per opleidingstype voor de provincie Noord-Holland 1989-1994 labsolute aantallen en als percentage van het aantal werkenden in 1989)

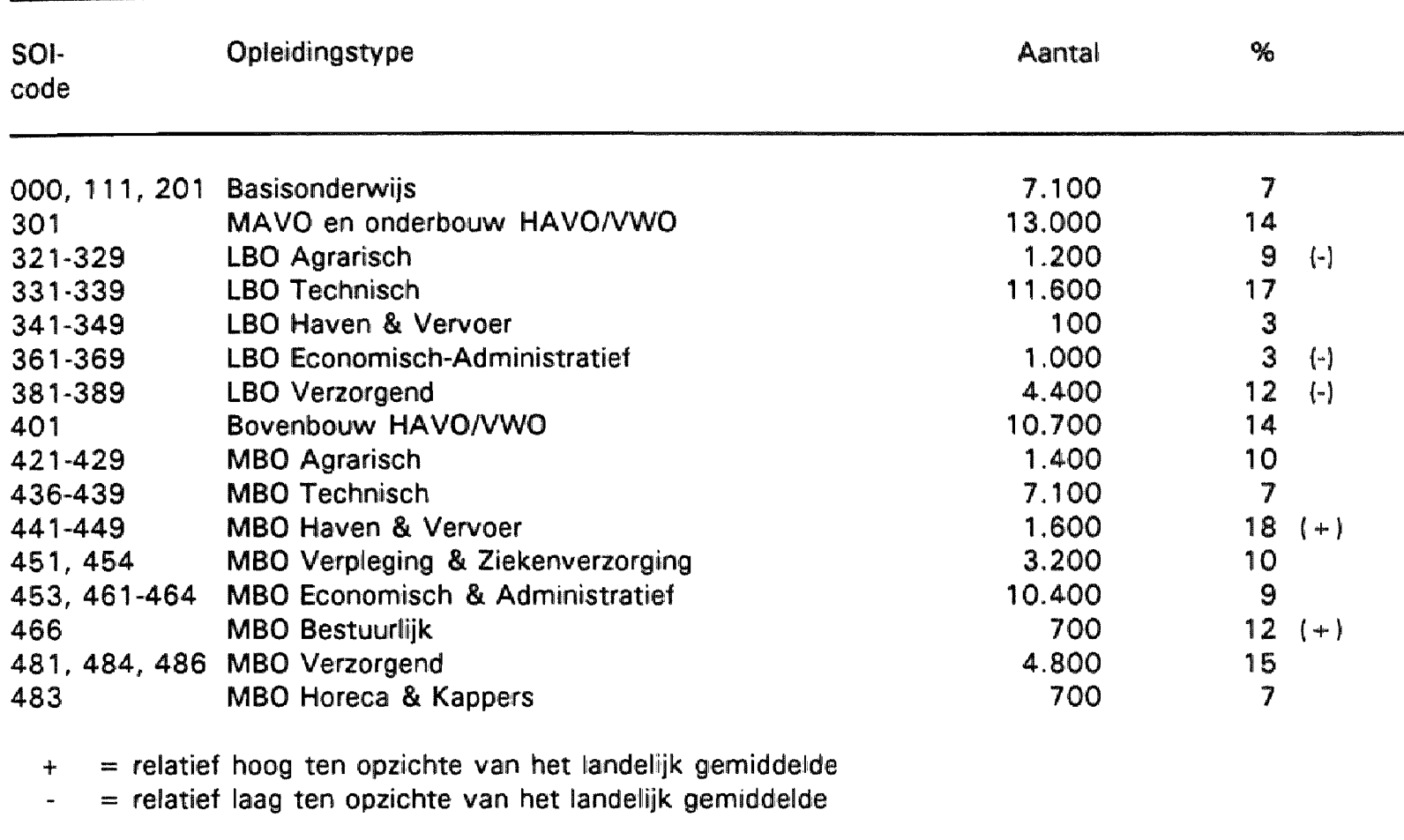

Bron: ROA

\subsection{Baanopeningen}

\section{Beroepen}

De totale vraag naar nieuwkomers, ofwel het toekomstige aantal baanopeningen, kan worden bepaald als de som van de werkgelegenheidsgroei (de positieve uitbreidingsvraag) en de vervangingsvraag. In tabel 3.7. zijn de beroepsklassen weergegeven waarvoor absoluut en relatief gezien veel baanopeningen worden verwacht. Tabel 3.8. geeft vervolgens een overzicht van de beroepsklassen met het in relatieve zin laagste aantal baanopeningen.

Voor de beroepsklasse 'Winkel-, straat- en marktverkopers, demonstrateurs' is de absolute vraag naar nieuwkomers naar verwachting het grootst. Er worden in deze beroepsklasse maar liefst bijna 25.000 baanopeningen verwacht. Relatief gezien worden de meeste baanopeningen verwacht voor de beroepsklasse 'Auteurs, journalisten, nieuwslezers, presentatoren'. Ook op landelijk niveau is voor deze beroepsklasse de totale vraag het grootst. Verder is het opvallend dat de beroepsklassen 'Politie-, brandweer- en bewakingspersoneel' en 'Beeldende en uitvoerende kunstenaars" in vergelijking met het landelijke beeld naar verwachting veel baanopeningen hebben. Voor de eerstgenoemde beroepsklasse hangt dit samen met een hoge uitbreidingsvraag, terwijl voor de laatstgenoemde beroepsklasse de vervangingsvraag in de provincie Noord-Holland naar verwachting relatief hoog is. Voor de beroepsklasse 'Technische tekenaars' is het verwachte aantal baanopeningen weliswaar hoog, maar duidelijk lager dan de 
landelijke prognose. Dit wordt veroorzaakt door een achterblijvende vervangingsvraag voor deze beroepsklasse.

Tabel 3.7. Beroepsklassen met de meeste baanopeningen in de provincie Noord-Holland 1989-1994 (absolute aantallen en als percentage van het aantal werkenden in 1989)

\section{Absoluut}

6211 Winkel-, straat- en marktverkopers, demonstrateurs

3021 Directeuren, bedrijfsleiders, leidinggevenden industrie

8212 Kinder-, gezins-, bejaardenverzorgenden e.a. verzorgend personeel

8211 Portiers, schoonmaak- e.a. lager dienstverlenend personeel

6031 Hogere leidinggevenden

7021 Auteurs, journalisten, nieuwslezers, presentatoren

4211 Conducteurs, chauffeurs e.a. transportmiddelenbestuurders

6125 Commercieel-administratieve employees

6124 Boekhoudkundige, belasting-, loket- en bankemplovees

8111 Koks, kelners e.a. keuken- en serveerpersoneel

$\begin{array}{rr}24.700 & 39 \\ 21.700 & 39 \\ 10.200 & 38 \\ 11.400 & 31 \\ 9.600 & 64 \\ 7.500 & 75 \\ 7.500 & 28 \\ 7.500 & 12 \\ 7.500 & 10 \\ 6.700 & 23\end{array}$

\section{Relatief}

7021 Auteurs, journalisten, nieuwslezers, presentatoren

7.500 75

6031 Hogere leidinggevenden

9.600

3031 Beta-onderzoekers, technische vakspecialisten

6211 Winkel-, straat- en marktverkopers, demonstrateurs

6.200

24.700

21.700

39

10.200

38

2.200

$37 \quad(-1)$

4.100

$321+1$

9121 Politie-, brandweer-en bewakingspersoneel

3.800

$321+1$

1331 Beeldende en uitvoerende kunstenaars

11.400

31

+ = relatief hoog ten opzichte van het landelijk gemiddelde

- = relatief laag ten opzichte van het landelijk gemiddelde

Bron: ROA

Voor vrijwel alle beroepsklassen waarvoor relatief weinig baanopeningen worden verwacht, wordt voor de periode 1989-1994 een werkgelegenheidsdaling voorspeld. Derhalve stemt de in tabel 3.8. weergegeven lijst in belangrijke mate overeen met de tabel met beroepsklassen met een lage verwachte vervangingsvraag. De relatief gezien minste baanopeningen worden verwacht voor de beroepsklassen 'Huis- scheeps- en constructieschilders' en 'Loodgieters, sanitairinstallateurs en -reparateurs". De toekomstige totale vraag naar nieuwkomers bedraagt voor deze beroepsklassen slechts 100 personen, overeenkomend met $2 \%$ van het aantal werkenden in 1989. Voor de laatstgenoemde beroepsklasse is het verwachte aantal baanopeningen in de provincie Noord-Holland iets lager dan het landelijk verwachte beeld. Dit geldt ook voor de beroepsklassen 'Machinisten bouw en industrie' en 'Administratief leidinggevenden'. De beroepsklasse 'Docenten voortgezet en hoger onderwijs' heeft daarentegen naar verwachting een hoger aantal toekomstige baanopeningen ten opzichte van de landelijke prognose. 
Tabel 3.8. Beroepsklassen met de minste baanopeningen in de provincie Noord-Holland 1989-1994 labsolute aantallen en als percentage van het aantal werkenden in 1989)

\section{Relatief}

3913 Huis-, scheeps- en constructieschilders

3914 Loodgieters, sanitair-installateurs en -reparateurs

3012 Machinisten bouw en industrie

6121 Administratief leidinggevenden

3915 Overige bouwvaklieden, (spoor/weg- en reinigingswerkers

3911 Metselaars, tegelzetters, straatmakers, stukadoors

1321 Fotografen, filmers, vormgevers, etaleurs

3613 Lassers, constructiewerkers, edelmetaalsmeden

3614 Machinebank- en plaatwerkers, gereedschaps- en modelmakers

0132 Docenten voortgezet en hoger onderwijs

$\begin{array}{rrr}100 & 2 & \\ 100 & 2 & (-1) \\ 200 & 3 & (-1) \\ 200 & 3 & 1-1 \\ 400 & 4 & \\ 300 & 7 & \\ 800 & 8 & \\ 700 & 9 & \\ 900 & 9 & \\ 2.900 & 10 & 1+1\end{array}$

$+\quad=$ relatief hoog ten opzichte van het landelijk gemiddelde

- $\quad=$ relatief laag ten opzichte van het landelijk gemiddelde

Bran: ROA

Opleidingen

Tabel 3.9. Baanopeningen per opleidingstype voor de provincie Noord-Holland 1989-1994 labsolute aantallen en als percentage van het aantal werkenden in 1989)

$\begin{array}{lll}\text { SOl- } & \text { Opleidingstype } & \text { Aantal }\end{array}$

$\begin{array}{llrrr}000,111,201 & \text { Basisonderwijs } & 7.100 & 7 \\ 301 & \text { MAVO en onderbouw HAVO/VWO } & 13.700 & 15 & (-1) \\ 321-329 & \text { LBO Agrarisch } & 1.200 & 9 & (-1) \\ 331-339 & \text { LBO Technisch } & 11.600 & 17 & \\ 341-349 & \text { LBO Haven \& Vervoer } & 1.100 & 22 \\ 361-369 & \text { LBO Economisch-Administratief } & 2.600 & 9 & (-1) \\ 381-389 & \text { LBO Verzorgend } & 10.500 & 29 \\ 401 & \text { Bovenbouw HAVO/NWO } & 12.800 & 16 \\ 421-429 & \text { MBO Agrarisch } & 1.400 & 10 \\ 436-439 & \text { MBO Technisch } & 14.700 & 14 \\ 441-449 & \text { MBO Haven \& Vervoer } & 2.500 & 28 \\ 451,454 & \text { MBO Verpleging \& Ziekenverzorging } & 7.100 & 23 \\ 453,461-464 & \text { MBO Economisch \& Administratief } & 29.600 & 25 \\ 466 & \text { MBO Bestuurlijk } & 1.600 & 26 \\ 481,484,486 & \text { MBO Verzorgend } & 15.100 & 46 \\ 483 & \text { MBO Horeca \& Kappers } & 800 & 8 \\ +\quad=\text { relatief hoog ten opzichte van het landelijk gemiddelde } & & \\ +\quad=\text { relatief laag ten opzichte van het landelijk gemiddelde } & & \end{array}$

Bran: ROA

In tabel 3.9. wordt het verwachte aantal baanopeningen voor de verschillende opleidingstypen 
weergegeven. Van deze opleidingstypen heeft 'MBO Verzorgend' in relatief opzicht naar verwachting de meeste toekomstige baanopeningen, hetgeen overeenkomt met het landelijke beeld. Eveneens in overeenstemming met de landelijke prognose is de verwachting dat er voor ongeschoolden (opleidingstype 'Basisonderwijs') relatief weinig baanopeningen worden verwacht. Verder is de provinciale prognose voor de opleidingstypen 'MAVO en onderbouw HAVONWO', 'LBO Agrarisch' en 'LBO Economisch-Administratief' opvallend. Voor deze opleidingstypen worden in de nabije toekomst in vergelijking met het landelijke beeld weinig baanopeningen verwacht.

\subsection{Instroom van schoolverlaters}

De in de voorgaande paragrafen gepresenteerde prognoseresultaten hebben allemaal betrekking op de ontwikkelingen aan de vraagzijde van de arbeidsmarkt. Er kan echter slechts inzicht worden verkregen in de toekomstige arbeidsmarktpositie van de schoolverlaters met een bepaalde opleidingsachtergrond als naast deze vraagontwikkelingen ook de ontwikkelingen aan de aanbodzijde worden belicht. Tabel 3.10. geeft een overzicht van de verwachte instroom van schoolverlaters op de arbeidsmarkt ${ }^{11}$.

Tabel 3.10. Instroom van schoolverlaters per opleidingstype voor de provincie Noord-Holland 1989-1994 (absolute aantallen en als percentage van het aantal werkenden in 1989)

\begin{tabular}{|c|c|c|c|c|}
\hline $\begin{array}{l}\mathrm{SOl}^{-} \\
\text {code }\end{array}$ & Opleidingstype & Aantal & $\%$ & \\
\hline $000,111,201$ & Basisonderwijs & 17.500 & 17 & $1+1$ \\
\hline 301 & MAVO en onderbouw HAVONWW & 6.200 & 7 & \\
\hline $321-329$ & LBO Agrarisch & 1.900 & 15 & $1+1$ \\
\hline $331-339$ & LBO Technisch & 11.400 & 16 & $1+1$ \\
\hline $341-349$ & LBO Haven \& Vervoer & 500 & 10 & $i+1$ \\
\hline $361-369$ & LBO Economisch-Administratief & 3.300 & 12 & \\
\hline $381-389$ & LBO Verzorgend & 4.900 & 14 & $1+1$ \\
\hline 401 & Bovenbouw HAVO/NWO & 16.500 & 21 & $(-)$ \\
\hline $421-429$ & MBO Agrarisch & 3.500 & 27 & $1+1$ \\
\hline $436-439$ & MBO Technisch & 22.800 & 22 & \\
\hline $441-449$ & MBO Haven \& Vervoer & 1.100 & 13 & $(-1)$ \\
\hline 451,454 & MBO Verpleging \& Ziekenverzorging & 7.000 & 23 & $(-1)$ \\
\hline $453,461-464$ & MBO Economisch \& Administratief & 18.300 & 15 & $(-1)$ \\
\hline 466 & MBO Bestuurlijk & 400 & 7 & \\
\hline $481,484,486$ & MBO Verzorgend & 8.900 & 27 & \\
\hline 483 & MBO Horeca \& Kappers & 1.100 & 11 & $(-)$ \\
\hline \multicolumn{5}{|c|}{$=$ relatief hoog ten opzichte van het landelijk gemiddelde } \\
\hline
\end{tabular}

Bron: ROA

11. Daarnaast bestaat het aanbod van nieuwkomers op de arbeidsmarkt uit de (kortdurig) werklozen aan het begin van de prognoseperiode. Op deze, in vergelijking tot de verwachte instroom van schoolverlaters, doorgaans relatief kleine groep wordt in deze paragraaf verder niet ingegaan. 
De relatief hoogste instroom van schoolverlaters wordt in Noord-Holland verwacht voor de opleidingstypen 'MBO Agrarisch' en 'MBO Verzorgend'. Voor de opleidingstypen 'MAVO en onderbouw HAVONWO' en 'MBO Bestuurlijk' wordt daarentegen een relatief erg lage instroom verwacht. In de tabel valt bovendien onmiddellijk op dat de prognoseresultaten in veel gevallen duidelijk afwijkend zijn van de landelijke prognoses. Met name voor een groot aantal LBOopleidingstypen wordt een instroom van schoolverlaters verwacht die relatief hoog is ten opzichte van het landelijk gemiddelde. Daarentegen hebben enkele MBO-opleidingstypen een toekomstige arbeidsmarktinstroom die naar verwachting lager is dan het landelijke beeld.

\subsection{Typering toekomstige arbeidsmarktsituatie}

Op basis van een confrontatie van de hierboven weergegeven vraag- en aanbodprognoses kan een typering worden gegeven van de toekomstige arbeidsmarktsituatie per opleidingstype. Daarvoor wordt gebruik gemaakt van de door het ROA voor het landelijke informatiesysteem onderwijs-arbeidsmarkt ontwikkelde indicator toekomstige arbeidsmarktsituatie. Als de waarde van deze indicator gelijk is aan 1, wordt verwacht dat de toekomstige vraag en het toekomstige aanbod in evenwicht zijn (zie voor een nadere toelichting Dekker, De Grip, Berendsen, Wieling en Willems, 1992).

In tabel 3.11. wordt voor de verschillende opleidingstypen het toekomstig arbeidsmarktperspectief gepresenteerd. Het arbeidsmarktperspectief van de opleidingen wordt daarbij tevens getypeerd als 'goed', 'redelijk', 'matig' of 'slecht'. Bovendien is aangegeven of de provinciale typering gunstiger, dan wel ongunstiger is dan het landelijke beeld.

Uit de tabel blijkt dat vooral voor enkele opleidingstypen op middelbaar niveau een goed arbeidsmarktperspectief wordt verwacht. Voor de opleidingstypen 'MBO Verpleging \& Ziekenverzorging' en 'MBO Horeca \& Kappers' is het toekomstig arbeidsmarktperspectief naar verwachting redelijk en voor 'MBO Technisch' wordt, in overeenstemming met het landelijke beeld, een matig arbeidsmarktperspectief verwacht. De opleidingstypen 'Bovenbouw HAVO/NWO' en 'MBO Agrarisch' hebben zelfs een slecht toekomstig perspectief op de arbeidsmarkt.

Op LBO-niveau ontstaat een zeer divers beeld voor de verschillende opleidingsrichtingen. De opleidingstypen 'LBO Haven \& Vervoer' en 'LBO Verzorgend' worden gekenmerkt door een goed toekomstig arbeidsmarktperspectief. Voor 'MAVO en onderbouw HAVONWW' is de toekomstige situatie op de arbeidsmarkt naar verwachting redelijk en voor de opleidingstypen 'LBO Economisch-Administratief' en 'LBO Agrarisch' matig. Voor 'LBO Technisch' wordt voor de nabije toekomst een slecht arbeidsmarktperspectief verwacht. Dit geldt eveneens voor het opleidingstype 'Basisonderwijs'.

In het algemeen kan worden opgemerkt dat het provinciale beeld voor de diverse opleidingstypen slechts weinig afwijkt van de landelijke positie van deze opleidingen op de arbeidsmarkt. Voor de opleidingstypen 'MAVO en onderbouw HAVO/VWO', 'LBO Technisch' en 
'LBO Economisch-Administratief' wordt in Noord-Holland een iets minder gunstige positie op de arbeidsmarkt verwacht, terwijl voor het opleidingstype 'MBO Horeca \& Kappers' de situatie in Noord-Holland iets gunstiger is dan landelijk wordt verwacht.

Tabel 3.11. Toekomstige arbeidsmarktsituatie per opleidingstype voor de provincie Noord-Holland 19891994

\begin{tabular}{|c|c|c|c|c|}
\hline $\begin{array}{l}\text { SOl- } \\
\text { code }\end{array}$ & Opleidingstype & $\begin{array}{l}\text { Indicator toekomstige } \\
\text { arbeidsmarktsituatie }\end{array}$ & Typering & \\
\hline $000,111,201$ & Basisonderwijs & 1,43 & slecht & \\
\hline 301 & MAVO en onderbouw HAVO/VWO & 1,02 & redelijk & $(-1$ \\
\hline $321-329$ & LBO Agrarisch & 1.09 & matig & \\
\hline $331-339$ & LBO Technisch & 1,11 & slecht & $(-1$ \\
\hline $341-349$ & LBO Haven \& Vervoer & 0,93 & goed & \\
\hline $361-369$ & LBO Economisch-Administratief & 1,08 & matig & $(-1)$ \\
\hline $381-389$ & LBO Verzorgend & 0,94 & goed & \\
\hline 401 & Bovenbouw HAVO/VWO & 1,12 & slecht & \\
\hline $421-429$ & MBO Agrarisch & 1,32 & slecht & \\
\hline $436-439$ & MBO Technisch & 1,08 & matig & \\
\hline 441.449 & MBO Haven \& Vervoer & 0,89 & goed & \\
\hline 451,454 & MBO Verpleging \& Ziekenverzorging & 1,02 & redelijk & \\
\hline $453,461-464$ & MBO Economisch \& Administratief & 0.93 & goed & \\
\hline 466 & MBO Bestuurlijk & 0.85 & goed & \\
\hline $481,484,486$ & MBO Verzorgend & 0.89 & goed & \\
\hline 483 & MBO Horeca \& Kappers & 1,04 & redelijk & $1+1$ \\
\hline
\end{tabular}

Bron: ROA

Het is van belang om op te merken dat een slecht toekomstig arbeidsmarkt niet automatisch hoeft te leiden tot een hoge werkloosheid. Als reactie op mogelijke onevenwichtigheden op de arbeidsmarkt kan in de eerste plaats worden gedacht aan het accepteren van banen onder het niveau van de gevolgde opleiding ${ }^{12}$. In de tweede plaats zal in de praktijk door middel van omof bijscholing van de reeds werkzame bevolking of werklozen op eventuele tekorten of overschotten op de arbeidsmarkt worden ingespeeld. In de derde plaats kunnen regionale verschillen tussen vraag en aanbod voor een bepaald opleidingstype leiden tot geografische mobiliteit van zowell arbeidskrachten als werkgevers. Deze mobiliteit zal zich met name voordoen wanneer de arbeidsmarktperspectieven voor een bepaald opleidingstype in een regio sterk afwijken van de arbeidsmarktsituatie in andere (aangrenzende) regio's (zie ook Berendsen, De Grip, Wieling en Willems, 1992al.

12. In het rapport De arbeidsmarkt naar opleiding en beroep tot 1994 van ROA (1992) wordt uitgebreid ingegaan op enkele indicatoren die mede bepalend zijn voor de marktpositie van de diverse opleidingen. 


\section{LITERATUUR}

Berendsen, H., A. de Grip, M.H. Wieling, E.J.T.A. Willems (1992a), Regionale arbeidsmarktinformatie naar opleiding en beroep; een verkenning vanuit het ROA-informatiesysteem onderwijs-arbeidsmarkt, ROA-R-1992/2, Maastricht.

Berendsen, H., A. de Grip, M.H. Wieling, E.J.T.A. Willems (1992b), Arbeidsmarktinformatie naar opleiding en beroep voor de provincie Friesiand; tabellenoverzicht, ROA-W-1992/4, Maastricht.

Dekker, R.J.P., A. de Grip, H. Berendsen, M.H. Wieling, E.J.T.A. Willems (1992), Methodiek en structuur arbeidsmarktmodule /-See! 1991, ROA-W-1992/1, Maastricht.

Grip, A. de, R.K.W. van der Velden, M.H. Wieling (1991), Indicatoren aans/uiting onderwijsarbeidsmarkt MDGO, ROA-R-1991/2, Maastricht.

Researchcentrum voor Onderwijs en Arbeidsmarkt (1992), De arbeidsmarkt naar opleiding en beroep tot 1994, ROA-R-1992/1, Maastricht.

Wieling, M.H., A. de Grip, E.J.T.A. Willems (1990), Een systematische kwalitatieve typering van arbeidsmarktinformatie, ROA-W-1990/8, Maastricht.

Willems, E.J.T.A., A. de Grip (1990), Vervangingsvraagprognoses naar beroep en opleiding, ROA-W-1990/7, Maastricht. 

ARBEIDSMARKTINFORMATIE NAAR OPLEIDING EN BEROEP VOOR DE PROVINCIE NOORD-HOLLAND

TABELLENOVERZICHT 
$-28-$

Tabel 1. Leeftiidsopbouw werkzame bevolking per provincie (gemiddelde 1988-1990)

\begin{tabular}{lcccc}
\hline Provincie & $\begin{array}{c}\text { Tot } 30 \text { jaar } \\
\%\end{array}$ & $\begin{array}{c}30-39 \text { jaar } \\
\%\end{array}$ & $\begin{array}{c}40-49 \text { jaar } \\
\%\end{array}$ & $\begin{array}{c}\text { Vanaf } 50 \text { jaar } \\
\%\end{array}$ \\
\hline Groningen & 36 & 26 & 23 & 15 \\
Friesland & 36 & 28 & 23 & 14 \\
Drenthe & 34 & 27 & 23 & 15 \\
Overijssel & 37 & 26 & 22 & 15 \\
Gelderland & 36 & 26 & 22 & 15 \\
Utrecht & 36 & 27 & 22 & 15 \\
Noord-Holland & 35 & 28 & 22 & 15 \\
Zuid-Holland & 35 & 28 & 22 & 15 \\
Zeeland & 34 & 28 & 22 & 16 \\
Noord-Brabant & 36 & 27 & 23 & 15 \\
Limburg & 34 & 28 & 23 & 10 \\
Flevoland & 36 & 32 & 21 & 15 \\
Totaal & 36 & 27 & 22 & \\
\hline
\end{tabular}

Bron: CBS/ROA 
Tabel 2. Conjunctuurgevoeligheild per provincie

Provincie

Conjunctuurindicator

Groningen

Friesland

Drenthe

Overijssel

Gelderland

Utrecht

Noord-Holland

Zuid-Holland

Zeeland

Noord-Brabant

Limburg

Flevoland
1,64

1,67

1,68

$1,77(+)$

1,70

$1,60 \quad(-)$

$1,60 \quad(-1$

1,59 (-)

1,70

$1,84(+)$

$1,78(+)$

$1,48 \quad(-)$

$+\quad=$ relatief hoge conjunctuurgevoeligheid

- $=$ relatief lage conjunctuurgevoeligheid 
Tabel 3. Aantal werkenden en percentage van de totale werkgelegenheid per bedrijfssector voor de provincie Noord-Holland Igemiddelde 1988-1990)

\begin{tabular}{|c|c|c|c|c|}
\hline Bedriffssector & Aantal & $\%$ & & Trend \\
\hline Landbouw, visserij en bosbouw & 31000 & 3 & $(-)$ & constant \\
\hline Voedings- en genotmiddelenindustrie & 20000 & 2 & & constant \\
\hline Kleding-en schoenenindustrie & 6000 & 1 & & stijgend \\
\hline Hout" en bouwmaterialenindustrie & 7000 & 1 & & dalend \\
\hline Papier- en grafische industrie & 33000 & 3 & & dalend \\
\hline Chemie & 17000 & 2 & & constant \\
\hline Metaalindustrie & 46000 & 4 & & stijgend \\
\hline Elektrotechnische industrie & 12000 & 1 & & dalend \\
\hline Transportmiddelenindustrie & 9000 & 1 & & stijgend \\
\hline Energie & 9000 & 1 & & constant \\
\hline Bouw & 53000 & 5 & & constant \\
\hline Handel & 164000 & 16 & & constant \\
\hline Vervoer en communicatie & 79000 & 8 & $1+1$ & constant \\
\hline Banken en verzekeringen & 53000 & 5 & $i+i$ & constant \\
\hline Horeca & 33000 & 3 & & constant \\
\hline Overige commerciële dienstverlening & 135000 & 13 & $1+1$ & constant \\
\hline Gezondheidszorg & 83000 & 8 & & constant \\
\hline Maatschappelijke dienstverlening & 104000 & 10 & & constant \\
\hline Openbaar bestuur, politie en defensie & 86000 & 8 & & constant \\
\hline Onderwijs & 64000 & 6 & & constant \\
\hline Totaal (incl. woningbezit en bedrijfssector onbekend) & 1050000 & 100 & & \\
\hline
\end{tabular}

Bron: CBS/ROA 
Tabel 4. Aantal werkenden en percentage van de totale werkgelegenheid per beroepsklasse voor de provincie Noord-Holland (gemiddelde 1988-1990)

ROA-Beroepsklasse Aantal $\% \quad$ Typering Trend
code

\section{O PEDAGOGISCHE BEROEPEN}

0131 Leerkrachten basis- en speciaal onderwijs

0132 Docenten voortgezet en hoger onderwijs

0133 Schoolhoofden e.a. onderwijskundige beroepen

\section{CULTURELE BEROEPEN}

1321 Fotografen, filmers, vormgevers, etaleurs

1331 Beeldende en uitvoerende kunstenaars

\section{AGRARISCHE BEROEPEN}

2011 Uitvoerend agrarisch personeel, bosarbeiders

2012 Zelfstandige agrariërs, boswachters

\section{TECHNISCHE, AMBACHTS- EN INDUSTRIEBEROEPEN}

3021 Directeuren, bedrijfsleiders, leidinggevenden industrie

3023 Technische tekenaars

3031 Beta-onderzoekers, technische vakspecialisten

3911 Voedingsmiddelenbereiders

3312 Houtbewerkers, timmerlieden

3411 Drukkers, boekbinders, fotolaboranten

3613 Lassers, constructiewerkers, edelmetaalsmeden

3614 Machinebank- en plaatwerkers, gereedschaps-en modelmakers

3615 Onderhoudsmonteurs, fietsen- en instrumentmakers

3621 Auto-, motor- en bromfietsmonteurs

3721 Elektriciens, elektro- en telecom(onderhouds)monteurs

3911 Metselaars, tegelzetters, straatmakers, stukadoors

3913 Huis-, scheeps- en constructieschilders

3914 Loodgieters, sanitair-installateurs en -reparateurs

3915 Overige bouwvaklieden, (spoor)weg- en reingingswerkers

\begin{tabular}{|c|c|c|c|}
\hline 57000 & 5 & erg hoog & constant \\
\hline 5000 & 0 & gemiddeld & stijgend \\
\hline 9000 & 1 & gemiddeld & stijgend \\
\hline 6000 & 1 & gemiddeld & constant \\
\hline 16000 & 2 & hoog & dalend \\
\hline 11000 & 1 & hoog & dalend \\
\hline 7000 & 1 & gemiddeld & stijgend \\
\hline 9000 & 1 & gemiddeld & stijgend \\
\hline 10000 & 1 & hoog & stijgend \\
\hline 7000 & 1 & gemiddeld & stijgend \\
\hline 17000 & 2 & hoog & constant \\
\hline 5000 & 0 & gemiddeld & constant \\
\hline 5000 & 1 & gemıddeld & dalend \\
\hline 7000 & 1 & gemıddeld & stygend \\
\hline 12000 & 1 & hoog & stijgend \\
\hline
\end{tabular}

\section{TRANSPORTBEROEPEN}

4011 Laders, lossers, vul- en inpak(machine)bedienden

4211 Conducteurs, chauffeurs e.a. transportmiddelenbestuurders

4321 Vliegers, boordwerktuigkundigen, transportdienstleiders

19000

24000

7000
20000

13000

$\begin{array}{rlll}18000 & 2 & \text { hoog } & \text { constant } \\ 29000 & 3 & \text { erg hoog } & \text { constant } \\ 7000 & 1 & \text { gemiddeld } & \text { dalend }\end{array}$

8000

gemiddeld

hoog

constant

stijgend

constant

hoog

hoog dalend

\section{MEDISCHE EN PARAMEDISCHE BEROEPEN}

5021 Gediplomeerde verpleegkundigen, verloskundigen

5022 Leerling-verpleegkundigen, zieken- en kraamverzorgenden

5031 Fysio-, arbeids- e.a. bewegingstherapeuten

5033 Geneeskundigen, medische adviseurs, apothekers

$\begin{array}{rlll}22000 & 2 & \text { hoog } & \text { stijgend } \\ 15000 & 1 & \text { hoog } & \text { constant } \\ 7000 & 1 & \text { gemiddeld } & \text { stijgend } \\ 7000 & 1 & \text { gemiddeld } & \text { constant }\end{array}$


Tabel 4. Aantal werkenden en percentage van de totale werkgelegenheid per beroepsklasse voor de provincie Noord-Holland lgemiddelde 1988-19901, vervolg

ROA- Beroepsklasse

code
Aantal $\% \quad$ Typering Trend

6 ECONOMISCH-ADMINISTRATIEVE BEROEPEN

6031 Hogere leidinggevenden

6111 Postdistributiepersoneel

6121 Administratief leidinggevenden

6122 Secretaressen, typisten

6124 Boekhoudkundige, belasting-, loket-en bankemployees

6125 Commercieel-administratieve employees

6126 Telefonisten, balie-employees, enquêteurs e.d.

6131 Systeemanalisten, -programmeurs en -beheerders

6132 Accountants, economen e.a. economische specialisten

6211 Winkel-, straat- en marktverkopers, demonstrateurs

6221 Winkeliers e.a. detail- en groothandelaren

6222 In-/verkoopchefs, handels- en verzekeringsagenten, makellaars e.d.

6332 Juristen

\section{SOCIAAL-CULTURELE BEROEPEN}

7021 Auteurs, journalisten, nieuwslezers, presentatoren

7033 Maatschappelijk werkers, reclasseringsambtenaren

7034 Sociale wetenschapsbeoefenaren

\section{VERZORGENDE EN DIENSTVERLENENDE BEROEPEN}

8111 Koks, kelners e.a. keuken- en serveerpersoneel

8121 Houders en leidinggevenden horeca- en recreatiebedrijven

8211 Portiers, schoonmaak- e.a. lager dienstverlenend personeel

8212 Kinder-, gezins-, bejaardenverzorgenden e.a. verzorgend personeel

8221 Kappers, schoonheidsspecialisten

9 OPENBARE ORDE- EN VEILIGHEIDSBEROEPEN

9121 Politie-, brandweer- en bewakingspersoneel

9221 Beroepsmilitairen

Totaal (incl. beroep onbekend)
10000

11000

6000

$\begin{array}{rll}17000 & 2 & \text { hoog } \\ 11000 & 1 & \text { hoog } \\ 6000 & 1 & \text { gemiddeld } \\ 31000 & 3 & \text { erg hoog } \\ 72000 & 7 & \text { erg hoog } \\ 61000 & 6 & \text { erg hoog } \\ 18000 & 2 & \text { hoog } \\ 22000 & 2 & \text { hoog } \\ 11000 & 1 & \text { hoog } \\ 69000 & 7 & \text { erg hoog } \\ 25000 & 2 & \text { hoog } \\ 20000 & 2 & \text { hoog } \\ 6000 & 1 & \text { gemiddeld }\end{array}$

constant

stijgend

stijgend

constant

constant

constant

constant

stijgend

dalend

dalend

constant

constant

constant

$\begin{array}{rlll}29000 & 3 & \text { erg hoog } & \text { stijgend } \\ 11000 & 1 & \text { hoog } & \text { dalend } \\ 41000 & 4 & \text { erg hoog } & \text { constant } \\ 27000 & 3 & \begin{array}{l}\text { hoog } \\ \text { gemiddeld }\end{array} & \begin{array}{l}\text { dialend } \\ \text { stijgend }\end{array} \\ 6000 & 1 & & \end{array}$

constant dalend

Bron: CBS/ROA 
Tabel 5. Belangrijkste opleidingstypen per beroepsklasse voor de provincie Noord-Holland 1990

Aantal \%

3021 Directeuren, bedrijfsleiders, leidinggevenden industrie

LBO Technisch

6000

16000

MBO Technisch

$7000 \quad 12$

MBO Economisch \& Administratief

5000

6000

LBO Technisch

37

3721 Elektriciens, elektro- en telecom(onderhouds/monteurs MBO Technisch

10000

4011 Laders, lossers, vul- en inpak(machine)bedienden

Basisonderwijs

6000

29

4211 Conducteurs, chauffeurs e.a. transportmiddelenbestuurders

Basisonderwijs

$7000 \quad 30$

5021 Gediplomeerde verpleegkundigen, verloskundigen

MBO Verpleging \& Ziekenverzorging

13000

51

5022 Leerling-verpleegkundigen, zieken- en kraamverzorgenden

MBO Verpleging \& Ziekenverzorging

$8000 \quad 50$

6122 Secretaressen, typisten

MBO Economisch \& Administratief

9000

31

6124 Boekhoudkundige, belasting-, loket- en bankemployees

MAVO en onderbouw HAVO/NWO

10000

8000

LBO Economisch-Administratief

10000

Bovenbouw HAVO/NWO

$20000 \quad 28$

6125 Commercieel-administratieve employees

MAVO en onderbouw HAVO/VWO

8000

8000

Bovenbouw HAVO/VWO

MBO Economisch \& Administratief

$15000 \quad 24$

6211 Winkel-, straat- en marktverkopers, demonstrateurs

Basisonderwijs

MAVO en onderbouw HAVO/NWO

$13000 \quad 19$

LBO Verzorgend

15000

6000

BovenbouW HAVO/NWO

$8000 \quad 11$

MBO Economisch \& Administratief

$8000 \quad 11$

6221 Winkeliers e.a. detail- en groothandelaren

MBO Economisch \& Administratief

9000

37

6222 In-/verkoopchefs, handels- en verzekeringsagenten, makelaars e.d.

MBO Economisch \& Administratief

7000

8111 Koks, kelners e.a. keuken- en serveerpersoneel

Basisonderwijs

7000

20 
$-34-$

Tabel 5. Belangrijkste opleidingstypen per beroepsklasse voor de provincie Noord-Holland 1990, vervolg

Aantal \%

8211 Portiers, schoonmaak- e.a. lager dienstverlenend personeel

Basisonderwijs

$15000 \quad 34$

MAVO en onderbouw HAVO/VWO

$6000 \quad 12$

LBO Verzorgend

$5000 \quad 11$

8212 Kinder-, gezins-, bejaardenverzorgenden e.a. verzorgend personeel MBO Verzorgend

Bron: CBS/ROA 
Tabel 6. Belangrijkste bedrijfssectoren per beroepsklasse voor de provincie Noord-Holland (gemiddelde 1988-1990)

Aantal $\% \quad$ Trend

0131 Leerkrachten basis- en speciaal onderwijs

Onderwijs

0132 Docenten voortgezet en hoger onderwijs

Onderwijs

1331 Beeldende en uitvoerende kunstenaars

Maatschappelijke dienstverlening

2011 Uitvoerend agrarisch personeel, bosarbeiders

Landbouw, visserij en bosbouw

2012 Zelfstandige agrariërs, boswachters

Landbouw, visserij en bosbouw

3021 Directeuren, bedrijfsleiders, leidinggevenden industrie

Metaalindustrie

Bouw

Overige commerciële dienstverlening

3312 Houtbewerkers, timmerlieden

Bouw

3411 Drukkers, boekbinders, fotolaboranten

Papier-en grafische industrie

3621 Auto-, motor- en bromfietsmonteurs

Overige commerciële dienstverlening

3994 Loodgieters, sanitair-installateurs en -reparateurs

Bouw

3915 Overige bouwvaklieden, (spoor)weg- en reinigingswerkers

Overige commerciële dienstverlening

4011 Laders, lossers, vul- en inpak(machine)bedienden

Handel

4211 Conducteurs, chauffeurs e.a. transportmiddelenbestuurders

Vervoer en communicatie

$15000 \quad 61 \quad$ dalend

5021 Gediplomeerde verpleegkundigen, verloskundigen

Gezondheidszorg

5022 Leerling-verpleegkundigen, zieken- en kraamverzorgenden

Gezondheidszorg

10000

68

dalend

5031 Fysio-, arbeids- e.a. bewegingstherapeuten

Gezondheidszorg

$6000 \quad 80 \quad$ constant

5033 Geneeskundigen, medische adviseurs, apothekers

Gezondheidszorg

\begin{tabular}{|c|c|c|}
\hline 16000 & 92 & constant \\
\hline 27000 & 93 & constant \\
\hline 19000 & 88 & constant \\
\hline 15000 & 76 & constant \\
\hline 12000 & 92 & constant \\
\hline 7000 & 11 & constant \\
\hline 8000 & 14 & stijgend \\
\hline 11000 & 20 & dalend \\
\hline 10000 & 60 & constant \\
\hline 8000 & 81 & constant \\
\hline 5000 & 71 & dalend \\
\hline 5000 & 79 & constant \\
\hline 7000 & 45 & onbekend \\
\hline 7000 & 36 & constant \\
\hline 15000 & 61 & dalend \\
\hline 19000 & 86 & constant \\
\hline 10000 & 68 & dalend \\
\hline 6000 & 80 & constant \\
\hline 6000 & 85 & stijgend \\
\hline
\end{tabular}


Tabel 6. Belangrijkste bedrijfssectoren per beroepsklasse voor de provincie Noord-Holland lgemiddelde 1988-19901, vervolg

Aantal $\% \quad$ Trend

6111 Postdistributiepersoneel

Vervoer en communicatie

\begin{tabular}{|c|c|c|}
\hline 8000 & 75 & stijgend \\
\hline 7000 & 23 & dalend \\
\hline $\begin{array}{r}16000 \\
5000\end{array}$ & $\begin{array}{r}21 \\
7\end{array}$ & $\begin{array}{l}\text { dalend } \\
\text { stijgend }\end{array}$ \\
\hline 22000 & 31 & constan \\
\hline $\begin{array}{l}8000 \\
7000\end{array}$ & $\begin{array}{r}12 \\
9\end{array}$ & $\begin{array}{l}\text { stijgend } \\
\text { dalend }\end{array}$ \\
\hline
\end{tabular}

6125 Commercieel-administratieve employees

Handel

Vervoer en communicatie

$10000 \quad 17$

$7000 \quad 11$

600010

Banken en verzekeringen

$7000 \quad 11$

Overige commerciële dienstverlening

12000

20

dalend

sterk stijgend

constant

Openbaar bestuur, politie en defensie

6131 Systeemanalisten, -programmeurs en -beheerders

Overige commerciële dienstverlening

6000

29

constant

6132 Accountants, economen e.a. economische specialisten

Overige commerciöle dienstverlening

$5000 \quad 46 \quad$ dalend

6211 Winkel-, straat en marktverkopers, demonstrateurs

Papier- en grafische industrie

60009 dalend

Handel

52000

75

constant

Overige commerciële dienstverlening

6000

stijgend

6221 Winkeliers e.a. detail- en groothandelaren

Handel

23000

constant

6222 In-/verkoopchefs, handels- en verzekeringsagenten, makelaars e.d. Handel

6000

dalend

7033 Maatschappelijk werkers, reclasseringsambtenaren Maatschappelijke dienstverlening

7000

61

constant

8111 Koks, kelners e.a. keuken- en serveerpersoneel

Horeca

17000

constant

8121 Houders en leidinggevenden horeca- en recreatiebedrijven Horeca

$8000 \quad 73$ dalend

8211 Portiers, schoonmaak- e.a. lager dienstverlenend personeel

Overige commerciële dienstverlening

Maatschappelijke dienstverlening

$18000 \quad 44 \quad$ constant

$5000 \quad 12$ dalend

8212 Kinder-, gezins", bejaardenverzorgenden e.a. verzorgend personeel Maatschappelijke dienstverlening 
Tabel 6. Belangrijkste bedrijfssectoren per beroepsklasse voor de provincie Noord-Holland (gemiddelde 1988-1990), vervolg

Aantal $\% \quad$ Trend

8221 Kappers, schoonheidsspecialisten

Overige commercięle dienstverlening

$6000 \quad 97 \quad$ constant

9121 Politie-, brandweer- en bewakingspersoneel

Openbaar bestuur, politie en defensie

900071 dalend

9221 Beroepsmilitairen

Openbaar bestuur, politie en defensie

$8000 \quad 98 \quad$ constant 
Tabel 7. Uitbreidingsvraag per beroepsklasse voor de provincie Noord-Holland 1989-1994 labsolute aantallen en als percentage van het aantal werkenden in 1989)

\begin{tabular}{|c|}
\hline ROA- Beroepsklasse \\
\hline
\end{tabular}

\section{PEDAGOGISCHE BEROEPEN}

0131 Leerkrachten basis-en speciaal onderwijs

0132 Docenten voortgezet en hoger onderwijs

\section{CULTURELE BEROEPEN}

1321 Fotografen, filmers, vormgevers, etaleurs

1331 Beeldende en uitvoerende kunstenaars

\section{AGRARISCHE BEROEPEN}

2011 Uitvoerend agrarisch personeel, bosarbeiders $\quad-2800$

3012 Machinisten bouw en industrie

3021 Directeuren, bedrijfsleiders, leidinggevenden industrie

3023 Technische tekenaars

3031 Beta-onderzoekers, technische vakspecialisten

3111 Voedingsmiddelenbereiders

3312 Houtbewerkers, timmerlieden

3411 Drukkers, boekbinders, fotolaboranten

3613 Lassers, constructiewerkers, edelmetaalsmeden

3614 Machinebank- en plaatwerkers, gereedschaps- en modelmakers

3615 Onderhoudsmonteurs, fietsen- en instrumentmakers

3621 Auto-, motor- en bromfietsmonteurs

3721 Elektriciens, elektro- en telecomionderhouds/monteurs

3911 Metselaars. tegelzetters, straatmakers, stukadoors

3913 Huis-, scheeps- en constructieschilders

3914 Loodgieters, sanitair-installateurs en -reparateurs

3915 Overige bouwvaklieden, (spoor)weg- en reinigingswerkers$$
-500
$$$$
-10
$$

laag

erg hoog erg hoog erg hoog laag laag laag laag

laag

laag erg laag

gemiddeld

erg laag erg Jaag

erg laag

erg laag

\section{TRANSPORTBEROEPEN}

4011 Laders, lossers, vul- en inpak(machine)bedienden

4211 Conducteurs, chauffeurs e.a. transportmiddelenbestuurders

4321 Vliegers, boordwerktuigkundigen, transportdienstleiders

hoog

7

gemiddeld

\section{MEDISCHE EN PARAMEDISCHE BEROEPEN}


Tabel 7. Uitbreidingsuraag per beroepsklasse voor de provincie Noord-Holland 1989-1994 labsolute aantallen en als percentage van het aantal werkenden in 19891, vervolg

$\begin{array}{llll}\text { ROA- Beroepsklasse } & \text { Aantal } & \% & \text { Typering } \\ \text { Code } & & & \end{array}$

5022 Leerlling-verpleegkundigen, zieken-en kraamverzorgenden $\quad 1200$

5031 Fysio-, arbeids- e.a. bewegingstherapeuten 700

$\begin{aligned} 8 & \text { gemiddeld } \\ 9 & \text { gemiddeld } \\ -11 & \text { laag }\end{aligned}$

5033 Geneeskundigen, medische adviseurs, apothekers

$-700$ gemiddeld
laag

\section{ECONOMISCH-ADMINISTRATIEVE BEROEPEN}

6031 Hogere leidinggevenden

6111 Postdistributiepersoneel

6121 Administratief leidinggevenden

6122 Secretaressen, typisten

6124 Boekhoudkundige, belasting-, loket- en bankemployees

6125 Commercieel-administratieve employees

6126 Telefonisten, balie-employees, enquêteurs e.d.

6131 Systeemanalisten, -programmeurs en -beheerders

6132 Accountants, economen e.a. economische specialisten

6211 Winkel-, straat- en marktverkopers, demonstrateurs

6221 Winkeliers e.a. detail- en groothandelaren

6222 in-/verkoopchefs, handels- en verzekeringsagenten, makelaars e.d.

6332 Juristen

\section{SOCIAAL-CULTURELE BEROEPEN}

7021 Auteurs, journallisten, nieuwslezers, presentatoren 5900 7033 Maatschappelijk werkers, reclasseringsambtenaren 600

7034 Sociale wetenschapsbeoefenaren

erg hoog
hoog
laag
laag
laag
laag
laag
hoog
laag
hoog
gemiddeld
gemiddeld
hoog

$(-)$

$1-1$

\section{VERZORGENDE EN DIENSTVERLENENDE BEROEPEN}

8111 Koks, kelners e.a. keuken- en serveerpersoneel 2600

8121 Houders en leidinggevenden horeca- en recreatiebedrijven

erg hoog gemiddeld gemiddeld

8211 Portiers, schoonmaak- e.a. lager dienstverlenend personeel

gemideld

8212 Kinder-, gezins-, bejaardenverzorgenden e.a. verzorgend personeel

gemiddeld

noog

8221 Kappers, schoonheidsspecialisten

\section{OPENBARE ORDE- EN VEILIGHEIDSBEROEPEN}

9121 Politie-, brandweer-en bewakingspersoneel

$+=$ relatief hoog ten opzichte van het landelijk gemiddelde

- $=$ relatief laag ten opzichte van het landelijk gemiddelde 
Tabel 8. Vervangingsvraag per beroepsklasse voor de provincie Noord-Holland 1989-1994 labsolute aantallen en als percentage van het aantal werkenden in 1989)

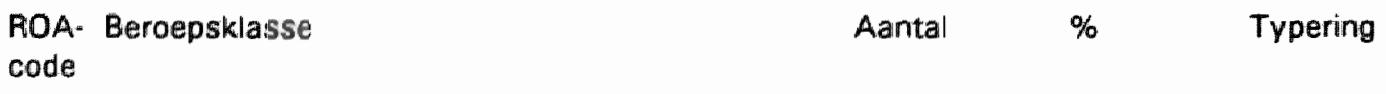

\section{PEDAGOGISCHE BEROEPEN}

0131 Leerkrachten basis- en speciaal onderwijs

0132 Docenten voortgezet en hoger onderwijs

0133 Schoolhoofden e.a. onderwijskundige beroepen

$\begin{array}{rlll}2500 & 14 & \text { gemiddeld } \\ 2900 & 10 & \text { gemiddeld } & 1+1 \\ 800 & 12 & \text { gemiddeld } & \end{array}$

1 CULTURELE BEROEPEN

1321 Fotografen, filmers, vormgevers, etaleurs

1331 Beeldende en uitvoerende kunstenaars

800

2900

8

laag

erg hoog $(+)$

\section{AGRARISCHE BEROEPEN}

2011 Uitvoerend agrarisch personeel, bosarbeiders

2100

1800

11

13

gemiddeld

gemiddeld

$(-)$

2012 Zelfstandige agrariërs, boswachters

3 TECHINISCHE-, AMBACHTS- EN INDUSTRIEBEROEPEN

3012 Machinisten bouw en industrie

200

3

erg laag

$(-)$

4300 industrie

300

3023 Technische tekenaars

1100

700

1800

3111 Voedingsmiddelenbereiders

2000

3411 Drukkers, boekbinders, fotolaboranten

700

3613 Lassers, constructiewerkers, edelmetaalsmeden

3614 Machinebank- en plaatwerkers, gereedschaps- en modelmakers

900

1900 instrumentmakers

3621 Auto-, motor- en bromfietsmonteurs

3721 Elektriciens, elektro-en telecom(onderhouds)monteurs

3911 Metselaars, tegeizetters, straatmakers, stukadoors

\section{8}

5

11

laag

erg laag

gemiddeld

gemiddeld

gemiddeld $(+)$

hoog $\quad(+)$

laag

9

laag

700

15

12

hoog $1+1$

gemiddeld $1+1$

1800

13

gemiddeld

300

100

7

2

laag

3913 Huis-, scheeps- en constructieschilders

3914 Loodgieters, sanitair-installateurs en -reparateurs

100

2

erg laag

400

4

erg laag

$(-)$

reinigingswerkers

4

erg laag

\section{TRANSPORTBEROEPEN}

4011 Laders, lossers, vul- en inpak(machine)bedienden

4211 Conducteurs, chauffeurs e.a. transportmiddelenbestuurders

2800

15

hoog

3600

13

gemiddeld

500

9

laag

$1+1$

\section{MEDISCHE EN PARAMEDISCHE BEROEPEN}

5021 Gediplomeerde verpleegkundigen, verloskundigen 
Tabel 8. Vervangingsvraag per beroepsklasse voor de provincie Noord-Holland 1989-1994 labsolute aantallen en als percentage van het aantal werkenden in 1989), vervolg

$\begin{array}{llll}\text { ROA- Beroepsklasse } & \text { Aantal } & \% & \text { Typering } \\ \text { code } & & & \end{array}$

5022 Leerling-verpleegkundigen, zieken- en kraamverzorgenden 3500

5031 Fysio-, arbeids- e.a. bewegingstherapeuten 900

5033 Geneeskundigen, medische adviseurs, apothekers 900

$\begin{array}{lll}22 & \text { erg hoog } & \\ 12 & \text { gemiddeld } \\ 16 & \text { hoog } \quad(+1\end{array}$

\section{ECONOMISCH-ADMINISTRATIEVE BEROEPEN}

6031 Hogere leidinggevenden

6111 Postdistributiepersoneel

6121 Administratief leidinggevenden

6122 Secretaressen, typisten

6124 Boekhoudkundige, belasting-, loket- en bankemployees

6125 Commercieel-administratieve employees

6126 Telefonisten, balie-employees, enquêteurs e.d.

6131 Systeemanalisten, -programmeurs en -beheerders

6132 Accountants, economen e.a. economische specialisten

6211 Winkel-, straat- en marktverkopers, demonstrateurs

6221 Winkeliers e.a. detail- en groothandelaren

$6222 \mathrm{ln}$-/verkoopchefs, handels- en verzekeringsagenten, makelaars e.d.

6332 Juristen

\section{SOCIAAL-CULTURELE BEROEPEN}

7021 Auteurs, journalisten, nieuwslezers, presentatoren 1600

7033 Maatschappelijk werkers, reclasseringsambtenaren 700

7034 Sociale wetenschapsbeoefenaren

1200
1000
200
3800
7500
7500
1800
1400
1500
11500
2200

2600
500


1600
700
800

\section{VERZORGENDE EN DIENSTVERLENENDE BEROEPEN}

8111 Koks, kelners e.a. keuken- en serveerpersoneel

8121 Houders en leidinggevenden horeca- en recreatiebedrijuen

4100

14

1500

8211 Portiers, schoonmaak- e.a. lager dienstverlenend personeel

8212 Kinder-, gezins-, bejaardenverzorgenden e.a.

verzorgend personeel

8221 Kappers, schoonheidsspecialisten

4400

2600

800

16

8

9

3

12

10

12

11

7

14

18

8

15

7 laag

laag

erg laag

gemiddeld

gemiddeld

gemiddeld

gemiddeld

laag

$1+1$

gemiddeld

hoog

laag

hoog

laag
(-)

(1)

$+1$

\section{OPENBARE ORDE- EN VEILIGHEIDSBEROEPEN}

9121 Politie-, brandweer- en bewakingspersoneel

9221 Beroepsmilitairen

hoog

$(+1$

laag

gemiddeld $1+1$

Totaal (incl. beroep onbekend)

124000

$+=$ relatief hoog ten opzichte van het landelijk gemiddelde

- $=$ relatief laag ten opzichte van het landelijk gemiddelde 
Tabel 9. Baanopeningen per beroepsklasse voor de provincie Noord-Holland 1989-1994 (absolute aantallen en als percentage van het aantal werkenden in 1989)

ROA- Beroepsklasse

Aantal $\%$

Typering

code

\section{PEDAGOGISCHE BEROEPEN}

0131 Leerkrachten basis-en speciaal onderwijs

gemiddeld

laag

laag

\section{CULTURELE BEROEPEN}

1321 Fotografen, filmers, vormgevers, etaleurs

800

1331 Beeldende en uitvoerende kunstenaars

3800

2100

1800

2012 Zelfstandige agrariërs, boswachters
11

13 laag

laag laag

hoog

3 TECHNISCHE, AMBACHTS- EN INDUSTRIEBEROEPEN

3012 Machinisten bouw en industrie 200 3 erg laag

3021 Directeuren, bedrijfsleiders, leidinggevenden industrie

21700

2200

39

3023 Technische tekenaars

6200

3031 Beta-onderzoekers, technische vakspecialisten

700

3191 Voedingsmiddelenbereiders

1800

3312 Houtbewerkers, timmerlieden

2000

3613 Lassers, constructiewerkers, edelmetaalsmeden

700

3614 Machinebank- en plaatwerkers, gereedschaps- en modelmakers

900

erg hoog

hoog

erg hoog

gemiddeld

laag $\quad(+1$

gemiddeld $i+1$

laag

3615 Onderhoudsmonteurs, fietsen- en instrumentmakers

1900

700

laag

3621 Auto-, motor- en bromfietsmonteurs

3721 Elektriciens, elektro- en telecom(onderhouds)monteurs

2600

gemiddeld $(+)$ laag $\quad(+1$

3911 Metselaars, tegelzetters, straatmakers, stukadoors

3913 Huis-, scheeps- en constructieschilders

300

100

gemiddeld $1+1$

3914 Loodgieters, sanitair-installateurs en -reparateurs

100

400

4

laag

erg laag

3915 Overige bouwvaklieden, (spoor)weg-en reinigingswerkers

2800

15

gemiddeld

4011 Laders, lossers, vul- en inpakimachine)bedienden

4211 Conducteurs, chauffeurs e.a. transportmiddelenbestuurders

7500

28

hoog

4321 Vliegers, boordwerktuigkundigen, transportdienstleiders

900

16

gemiddeld $(+)$

\section{MEDISCHE EN PARAMEDISCHE BEROEPEN}

5021 Gediplomeerde verpleegkundigen, verloskundigen 
Tabel 9. Baanopeningen per beroepsklasse voor de provincie Noord-Holland 1989-1994 (absolute aantallen en als percentage van het aantal werkenden in 1989), vervolg

\begin{tabular}{|c|c|}
\hline ROA. Beroepsklasse & Aantal \\
\hline
\end{tabular}

5022 Leerling-verpleegkundigen, zieken- en kraamverzorgenden

$4700 \quad 29 \quad$ hoog

5031 Fysio-, arbeids- e.a. bewegingstherapeuten $\quad 1600$

20

gemiddeld

5033 Geneeskundigen, medische adviseurs, apothekers

900

gemiddeld $1+1$

\section{ECONOMISCH-ADMINISTRATIEVE BEROEPEN}

6031 Hogere leidinggevenden

6111 Postdistributiepersoneel

6121 Administratief leidinggevenden

6122 Secretaressen, typisten

6124 Boekhoudkundige, belasting-, loket- en bankemployees

6125 Commercieel-administratieve employees

6126 Telefonisten, balie-employees, enquêteurs e.d.

6131 Systeemanalisten, -programmeurs en -beheerders

6132 Accountants, economen e.a. economische specialisten

6211 Winkel-, straat- en marktverkopers, demonstrateurs

6221 Winkeliers e.a. detail- en groothandelaren

$6222 \mathrm{In}$-/verkoopchefs, handels- en verzekeringsagenten, makelaars e.d.

6332 Juristen

\section{SOCIAAL-CULTURELE BEROEPEN}

7021 Auteurs, journalisten, nieuwslezers, presentatoren 7500

7033 Maatschappelijk werkers, reclasseringsambtenaren 1300

7034 Sociale wetenschapsbeoefenaren

1100

\section{VERZORGENDE EN DIENSTVERLENENDE BEROEPEN}

8111 Koks, kelners e.a. keuken- en serveerpersoneel

8121 Houders en leidinggevenden horeca- en recreatiebedrijven

6700

23

2000

18

11400 personeel

8212 Kinder-, gezins-, bejaardenverzorgenden e.a. verzorgend personeel

8221 Kappers, schoonheidsspecialisten

10200

1500

31

38

21

\section{OPENBARE ORDE- EN VEILIGHEIDSBEROEPEN}

9121 Politie-, brandweer- en bewakingspersoneel

9221 Beroepsmilitairen

4100

800

32

13

195100

19

Totaal (incl. beroep onbekend) erg hoog

gemiddeld

erg laag

laag

laag

laag

laag

gemiddeld

gemiddeld

erg hoog

gemiddeld

gemiddeld

hoog

erg hoog

laag

gemiddeld $(+)$

gemiddeld

gemiddeld

hoog

erg hoog

gemiddeld

hoog $\quad(+1$

laag (-)

9

$+=$ relatief hoog ten opzichte van het landelijk gemiddelde

- $=$ relatief laag ten opzichte van het landlelijk gemiddelde 
Tabel 10. Aantal werkenden en percentage van de totale werkgelegenheid per opleidingstype voor de provincie Noord-Halland 1990

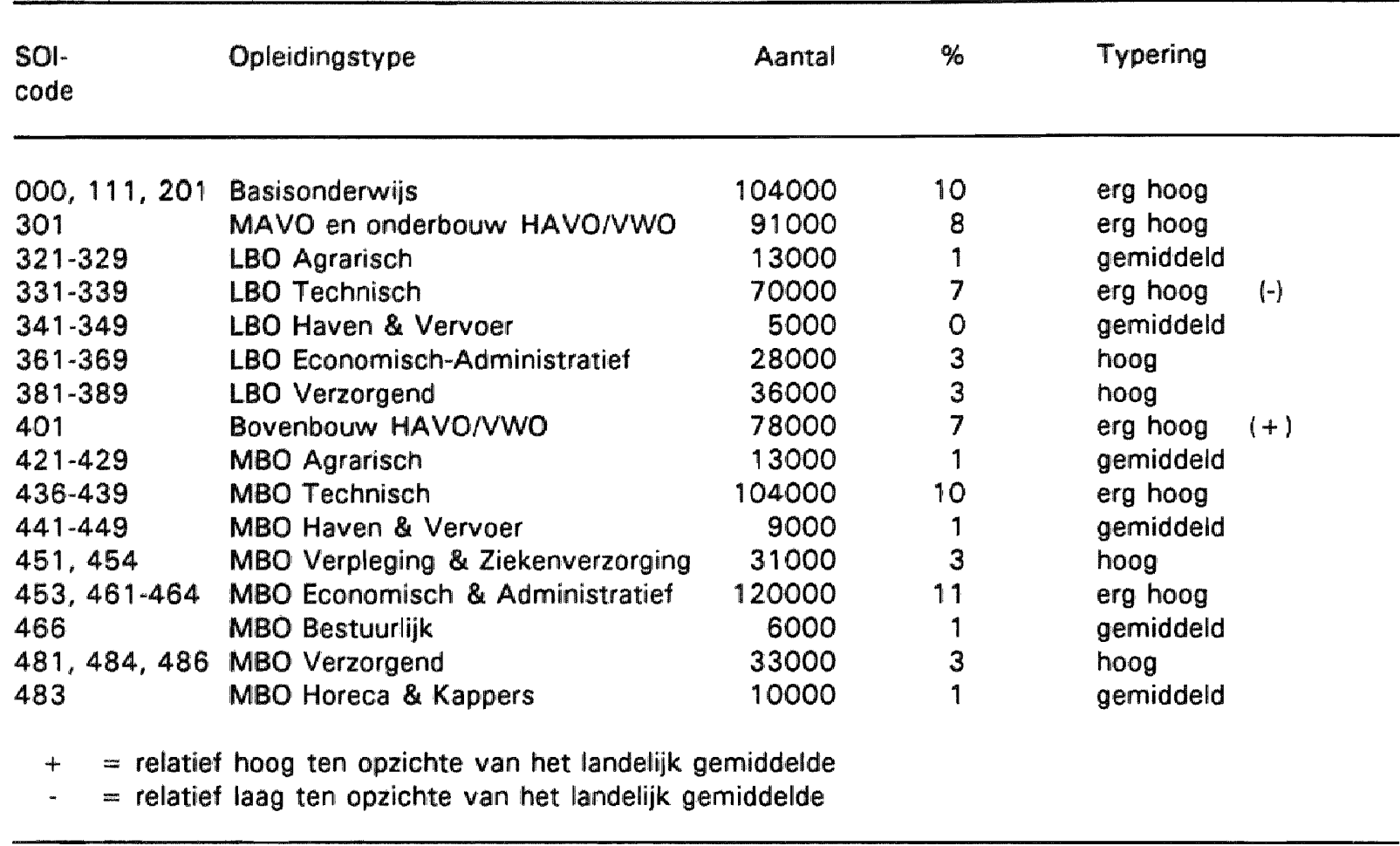

Bron: CBS/ROA 
Tabel 11. Belangrijkste beroepsklassen per opleidingstype voor de provincie Noord-Holland 1990

Aantal \%

000, 111, 201 Basisonderwijs

Laders, lossers, vul- en inpak(machine)bedienden

6000

7000

Conducteurs, chauffeurs e.a. transportmiddelenbestuurders

13000

Winkel-, straat- en marktverkopers, demonstrateurs

7000

Koks, kelners e.a. keuken- en serveerpersoneel

$15000 \quad 13$

Portiers, schoonmaak- e.a. lager dienstverlenend personeel

301

MAVO en onderbouw HAVONWO

Boekhoudkundige, belasting-, loket- en bankemployees

Commercieel-administratieve employees

$10000 \quad 11$

$8000 \quad 9$

Winkel-, straat- en marktverkopers, demonstrateurs

$15000 \quad 16$

Portiers, schoonmaak- e.a. lager dienstverlenend personeel

6000

6

331-339 LBO Technisch

Directeuren, bedrijfsleiders, leidinggevenden industrie

Houtbewerkers, timmerlieden

6000

5000

361-369 LBO Economisch-Administratief

Boekhoudkundige, belasting-, loket- en bankemployees

8000

$381-389$

LBO Verzorgend

Winkel-, straat- en marktverkopers, demonstrateurs

6000

$5000 \quad 14$

Portiers, schoonmaak- e.a. lager dienstverlenend personeel

5

401 Bovenbouw HAVO/VWO

Boekhoudkundige, belasting-, loket- en bankemployees

Commercieel-administratieve employees

$10000 \quad 13$

Winkel-, straat- en marktverkopers, demonstrateurs

$8000 \quad 10$

$8000 \quad 10$

436-439 MBO Technisch

Directeuren, bedrijfsleiders, leidinggevenden industrie

Houtbewerkers, timmerlieden

$16000 \quad 15$

Elektriciens, elektro- en telecom(onderhouds)monteurs

$6000 \quad 5$

$10000 \quad 10$

451,454

MBO Verpleging \& Ziekenverzorging

Gediplomeerde verpleegkundigen, verloskundigen

$13000 \quad 39$

Leerling-verpleegkundigen, zieken-en kraamverzorgenden

453, 461-464 MBO Economisch \& Administratief

Directeuren, bedrijfsleiders, leidinggevenden industrie

7000

6

Secretaressen, typisten

90008

Boekhoudkundige, belasting-, loket- en bankemplovees

20000

15000

Commercieel-administratieve employees

8000

Winkel-, straat- en marktverkopers, demonstrateurs

9000

In-/verkoopchefs, handels- en verzekeringsagenten, makelaars e.d. 7000

$481,484_{r} 486$ MBO Verzorgend

Kinder-, gezins-, bejaardenverzorgenden e.a. verzorgend personeel 7000 
Tabel 12. Belangrijkste bedrijfssectoren per opleidingstype voor de provincie Noord-Holland 1990

Aantal $\%$

000, 111, 201 Basisonderwijs

Landbouw, visserij en bosbouw

Metaalindustrie

$5000 \quad 5$

Bouw

80007

Handel

$7000 \quad 7$

Vervoer en communicatie

$22000 \quad 21$

Horeca

$10000 \quad 10$

Overige commerciêle dienstverlening

5000

Maatschappelijke dienstverlening

$13000 \quad 12$

80007

$301 \quad$ MAVO en onderbouw HAVONWO

Papier- en grafische industrie

5000

Handel

21000

9000

Vervoer en communicatie

6000

6000

Horeca

11000

Overige commerciële dienstverlening

Maatschappelijke dienstverlening

8000

Openbaar bestuur, politie en defensie

6000

6000

Landbouw, visserij en bosbouw

331-339 LBO Technisch

Metaalindustrie

9000

13

Bouw

$14000 \quad 20$

Handel

Vervoer en communicatie

11000

15

Overige commerciële dienstverlening

$7000 \quad 10$

$7000 \quad 10$

361-369 LBO Economisch-Administratief

$$
\text { Handel }
$$

$381-389$

LBO Verzorgend

Handel

9000

25

Maatschappelijke dienstverlening

$7000 \quad 18$

401

Bovenbouw HAVO/NWO

Handel

Vervoer en communicatie

$15000 \quad 19$

Banken en verzekeringen

$9000 \quad 12$

$7000 \quad 8$

Horeca

Overige commerciële dienstverlening

$5000 \quad 6$

Maatschappelijke dienstverlening

$12000 \quad 15$

Openbaar bestuur, politie en defensie

$10000 \quad 12$

60007

$421-429$

MBO Agrarisch

Landbouw, visserij en bosbouw

6000 
Tabel 12. Belangrijkste bedrijtssectoren per opleidingstype voor de provincie Noord-Holland 1990 , vervolg

Aantal \%

436-439 MBO Technisch

Papier- en grafische industrie $\quad 6000 \quad 5$

Metaalindustrie $\quad 11000 \quad 10$

Bouw $\quad 20000 \quad 19$

Handel $\quad 14000 \quad 13$

Vervoer en communicatie $10000 \quad 9$

Overige commerciële dienstverlening $\quad 15000 \quad 14$

$\begin{array}{lll}\text { Openbaar bestuur, politie en defensie } & 7000 & 6\end{array}$

451, 454 MBO Verpleging \& Ziekenverzorging

Gezondheidszorg

$21000 \quad 69$

Maatschappelijke dienstverlening

$5000 \quad 16$

453, 461-464 MBO Economisch \& Administratief

$31000 \quad 25$

Vervoer en communicatie

$11000 \quad 9$

Banken en verzekeringen

$17000 \quad 14$

Overige commerciële dienstverlening

$15000 \quad 13$

Maatschappelijke dienstverlening

80007

Openbaar bestuur, politie en defensie

$8000 \quad 6$

$481,484,486$ MBO Verzorgend

Gezondheidszorg $\quad 5000 \quad 15$

$\begin{array}{lll}\text { Maatschappelijke dienstverlening } & 12000 \quad 35\end{array}$

Bron: CBS/ROA 
$-48-$

Tabel 13. Werkloosheidspercentage per opleidingstype voor de provincie Noord-Holland april 1991 (bemiddelingsbestand zonder baan)

\begin{tabular}{|c|c|c|c|}
\hline $\begin{array}{l}\text { SOl- } \\
\text { code }\end{array}$ & Opleidingstype & $\%$ & Typering \\
\hline $000,111,201$ & Basisonderwijs & 25 & erg hoog \\
\hline 301 & MAVO en onderbouw HAVONWO & 19 & erg hoog \\
\hline $321-329$ & LBO Agrarisch & 6 & gemiddeld \\
\hline $331-339$ & LBO Technisch & 10 & hoog \\
\hline $341-349$ & LBO Haven \& Vervoer & 4 & gemiddeld \\
\hline $361-369$ & LBO Economisch-Administratief & 13 & erg hoog \\
\hline $381-389$ & LBO Verzorgend & 12 & erg hoog \\
\hline 401 & Bovenbouw HAVO/VWO & 17 & erg hoog \\
\hline $421-429$ & MBO Agrarisch & 2 & laag \\
\hline $436-439$ & MBO Technisch & 2 & laag \\
\hline $4.41-4.49$ & MBO Haven \& Vervoer & 1 & erg laag \\
\hline 451,454 & MBO Verpleging \& Ziekenverzorging & 3 & laag \\
\hline $453,461-464$ & MBO Economisch \& Administratief & 1 & erg laag \\
\hline 466 & MBO Bestuurlijk & 1 & erg laag \\
\hline $481,484,486$ & MBO Verzorgend & 4 & gemiddeld \\
\hline 483 & MBO Horeca \& Kappers & 2 & laag \\
\hline
\end{tabular}

Bron: Arbeidsvoorzieningsorganisatie/ROA 
Tabel 14. Bedrijfssectorspreiding per opleidingstype voor de provincie Noord-Holland 1990 /GiniHirschman indicator!

$\begin{array}{lcl}\text { SOl- } & \text { Opleidingstype } & \begin{array}{c}\text { Gini-Hirschman } \\ \text { indicator }\end{array}\end{array}$

$\begin{array}{ll}000,111,201 & \text { Basisonderwijs } \\ 301 & \text { MAVO en onderbouw HAVO/VWO } \\ 321-329 & \text { LBO Agrarisch } \\ 331-339 & \text { LBO Technisch } \\ 341-349 & \text { LBO Haven \& Vervoer } \\ 361-369 & \text { LBO Economisch-Administratief } \\ 381-389 & \text { LBO Verzorgend } \\ 401 & \text { Bovenbouw HAVO/NWO } \\ 421-429 & \text { MBO Agrarisch } \\ 436-439 & \text { MBO Technisch } \\ 441-449 & \text { MBO Haven \& Vervoer } \\ 451,454 & \text { MBO Verpleging \& Ziekenverzorging } \\ 453,461-464 & \text { MBO Economisch \& Administratief } \\ 466 & \text { MBO Bestuurlijk } \\ 481,484,486 & \text { MBO Verzorgend } \\ 483 & \text { MBO Horeca \& Kappers }\end{array}$

$\begin{array}{ll}0.95 & \text { groot } \\ 0.94 & \text { groot } \\ 0.78 & \text { gemiddeld } \\ 0.93 & \text { groot } \\ 0.76 & \text { gemiddeld } \\ 0.90 & \text { groot } \\ 0.91 & \text { groot } \\ 0.94 & \text { groot } \\ 0.79 & \text { gemiddeld } \\ 0.94 & \text { groot } \\ 0.82 & \text { gemiddeld } \\ 0.52 & \text { erg klein } \\ 0.92 & \text { groot } \\ 0.54 & \text { erg klein } \\ 0.85 & \text { gemiddeld } \\ 0.84 & \text { gemiddeld }\end{array}$

Bron: ROA 
Tabel 15. Uitbreidingsvraag per opleidingstype voor de provincie Noord-Holland 1989-1994 labsolute aantallen en als percentage van het aantal werkenden in 1989)

\begin{tabular}{lllll}
\hline SOl- Opleidingstype & Aantal & $\%$ & Typering
\end{tabular}

code

$\begin{array}{ll}000,111,201 & \text { Basisonderwijs } \\ 301 & \text { MAVO en onderbouw HAVONWO } \\ 321-329 & \text { LBO Agrarisch } \\ 331-339 & \text { LBO Technisch } \\ 341-349 & \text { LBO Haven \& Vervoer } \\ 361-369 & \text { LBO Economisch-Administratief } \\ 381-389 & \text { LBO Verzorgend } \\ 401 & \text { Bovenbouw HAVO/VWO } \\ 421-429 & \text { MBO Agrarisch } \\ 436-439 & \text { MBO Technisch } \\ 441-449 & \text { MBO Haven \& Vervoer } \\ 451,454 & \text { MBO Verpleging \& Ziekenverzorging } \\ 453,461-464 & \text { MBO Economisch \& Administratief } \\ 466 & \text { MBO Bestuurlijk } \\ 481,484,486 & \text { MBO Verzorgend } \\ 483 & \text { MBO Horeca \& Kappers }\end{array}$

$\begin{array}{rrll}-11400 & -11 & \text { erg laag } & \\ 700 & 1 & \text { laag } & \\ 0 & 0 & \text { laag } \quad 1+1 \\ -4000 & -6 & \text { erg laag } & \\ 1000 & 19 & \text { hoog } & \\ 1700 & 6 & \text { gemiddeld } \\ 6100 & 17 & \text { gemiddeld } \\ 2100 & 3 & \text { laag } & \\ -1600 & -13 & \text { erg laag } \\ 7600 & 7 & \text { gemiddeld } \\ 900 & 10 & \text { gemiddeld } \\ 3900 & 13 & \text { gemiddeld } \\ 19100 & 16 & \text { gemiddeld } \\ 800 & 14 & \text { gemiddeld } \\ 10200 & 31 & \text { erg hoog } \\ 100 & 1 & \text { laag }\end{array}$

- = relatief laag ten opzichte van het landelijk gemiddelde

Bron: ROA 
Tabel 16. Vervangingsvraag per opleidingstype voor de provincie Noord-Holland 1989-1994 (absolute aantallen en als percentage van het aantal werkenden in 1989)

\begin{tabular}{|c|c|c|c|c|}
\hline $\begin{array}{l}\text { SOl- } \\
\text { code }\end{array}$ & Opleidingstype & Aantal & $\%$ & Typering \\
\hline $000,111,201$ & Basisonderwijs & 7100 & 7 & laag \\
\hline 301 & MAVO en onderbouw HAVONWO & 13000 & 14 & hoog \\
\hline $321-329$ & LBO Agrarisch & 1200 & 9 & gemiddeld \\
\hline $331-339$ & LBO Technisch & 11600 & 17 & erg hoog \\
\hline $341-349$ & LBO Haven \& Vervoer & 100 & 3 & erg laag \\
\hline $361-369$ & LBO Economisch-Administratief & 1000 & 3 & erg laag \\
\hline $381-389$ & LBO Verzargend & 4400 & 12 & gemiddeld \\
\hline 401 & Bovenbouw HAVO/VWO & 10700 & 14 & hoog \\
\hline $421-429$ & MBO Agrarisch & 1400 & 10 & gemiddeld \\
\hline $436-439$ & MBO Technisch & 7100 & 7 & laag \\
\hline $441-449$ & MBO Haven \& Vervoer & 1600 & 18 & erg hoog \\
\hline 451,454 & MBO Verpleging \& Ziekenverzorging & 3200 & 10 & gemiddeld \\
\hline $453,461-464$ & MBO Economisch \& Administratief & 10400 & 9 & gemiddeld \\
\hline 466 & MBO Bestuurlijk & 700 & 12 & gemiddeld $(+1)$ \\
\hline $481,484,486$ & MBO Verzorgend & 4800 & 15 & hoog \\
\hline 483 & MBO Horeca \& Kappers & 700 & 7 & laag \\
\hline
\end{tabular}

Bron: ROA 
Tabel 17. Baanopeningen per opleidingstype voor de provincie Noord-Holland 1989-1994 labsolute aantallen en als percentage van het aantal werkenden in 1989)

\begin{tabular}{|c|c|c|c|c|c|}
\hline $\begin{array}{l}\text { SOI- } \\
\text { code }\end{array}$ & Opleidingstype & Aantal & $\%$ & Typering & \\
\hline $000,111,201$ & Basisonderwijs & 7100 & 7 & erg laag & \\
\hline 301 & MAVO en onderbouw HAVONWO & 13700 & 15 & laag & $(-)$ \\
\hline $321-329$ & LBO Agrarisch & 1200 & 9 & laag & $(-)$ \\
\hline $331-339$ & LBO Technisch & 11600 & 17 & gemiddeld & \\
\hline $341-349$ & LBO Haven \& Vervoer & 1100 & 22 & gemiddeld & \\
\hline $361-369$ & LBO Economisch-Administratief & 2600 & 9 & laag & $(-1)$ \\
\hline $381-389$ & LBO Verzorgend & 10500 & 29 & hoog & \\
\hline 401 & Bovenbouw HAVONWW & 12800 & 16 & laag & \\
\hline $421-429$ & MBO Agrarisch & 1400 & 10 & laag & \\
\hline $436-439$ & MBO Technisch & 14700 & 14 & laag & \\
\hline $441-449$ & MBO Haven \& Vervoer & 2500 & 28 & noog & \\
\hline 451,454 & MBO Verpleging \& Ziekenverzorging & 7100 & 23 & gemiddeld & \\
\hline $453,461-464$ & MBO Economisch \& Administratief & 29600 & 25 & gemiddeld & \\
\hline 466 & MBO Bestuurlijk & 1600 & 26 & gemidleld & \\
\hline $481,484,486$ & MBO Verzorgend & 15100 & 46 & erg hoog & \\
\hline 483 & MBO Horeca \& Kappers & 800 & 8 & erg laag & \\
\hline
\end{tabular}

Bron: ROA 
Tabel 18. Instroom van schoolverlaters per opleidingstype voor de provincie Noord-Holland 1989-1994 labsolute aantallen en als percentage van het aantal werkenden in 1989 \}

sol-

code
Opleidingstype

$000,111,201$ Basisonderwijs

301

$321-329$

331-339

341-349

361.369

381-389

401

$421-429$

436-439

$441-449$

451,454

$453,461-464$

466

$481,484,486$

483

LBO Agrarisch

LBO Technisch
Aantal

MAVO en onderbouw HAVO/VWO

LBO Haven \& Vervoer

LBO Economisch-Administratief

LBO Verzorgend

Bovenbouw HAVO/VWO

MBO Agrarisch

MBO Technisch

MBO Haven \& Vervoer

MBO Verpleging \& Ziekenverzorging

MBO Economisch \& Administratief

MBO Bestuurlijk

MBO Verzorgend

MBO Horeca \& Kappers
17500

6200

1900

11400

500

3300

4900

16500

3500

22800

1100

7000

18300

400

8900

1100
$\%$

Typering

$+\quad=$ relatief hoog ten opzichte van het landelijk gemiddelde

- $\quad=$ relatief laag ten opzichte van het landelijk gemiddelde

Bron: ROA 
Tabel 19. Toekomstige arbeidsmarktsituatie per opleidingstype voor de provincie Noord-Holland 19891994

SOI-

Opleidingstype

Indicator toekomstige

Typering

code

arbeidsmarktsituatie

000, 111, 201 Basisonderwijs

1.43

1.02

1.09

321.329

MAVO en onderbouw HAVO/NWO

1.11

$331-339$

LBO Agrarisch

LBO Technisch

0.93

$341-349$

LBO Haven \& Vervoer

1.08

$381-389$

LBO Economisch-Administratief

0.94

LBO Verzorgend

1.12

401

Bovenbouw HAVO/VWO

1.32

MBO Agrarisch

$421-429$

MBO Technisch

1.08

MBO Haven \& Vervoer

0.89

441.449

451,454

MBO Verpleging \& Ziekenverzorging

1.02

0.93

453, 461-464 MBO Economisch \& Administratief

0.85

MBO Bestuurlijk

0.89

483

MBO Horeca \& Kappers

1.04

slecht

redelijk

$(-)$

matig

slecht

goed

matig

goed

slecht

slecht

matig

goed

redelijk

goed

goed

goed

redelijk $\quad(+1$

$+\quad=$ relatief gunstig ten opzichte van het landelijk gemiddelde

- = relatief ongunstig ten opzichte van het landelijk gemiddelde

Bron: ROA 
$-55-$

Tabel 20. Leeftijdsopbouw werkzame bevolking per RBA-gebied (gemiddelde 1989-1990)

\begin{tabular}{|c|c|c|c|c|}
\hline RBA-gebied & $\begin{array}{c}\text { Tot } 30 \text { jaar } \\
\%\end{array}$ & $\begin{array}{c}30-39 \text { jaar } \\
\%\end{array}$ & $\begin{array}{c}40-49 \text { jaar } \\
\%\end{array}$ & $\begin{array}{c}\text { Vanat } 50 \text { jaar } \\
\%\end{array}$ \\
\hline Groningen & 36 & 26 & 23 & 14 \\
\hline Friesland & 36 & 28 & 23 & 14 \\
\hline Drenthe & 34 & 27 & 24 & 15 \\
\hline IJssel-Vecht & 37 & 26 & 21 & 16 \\
\hline Twente & 37 & 26 & 23 & 14 \\
\hline Midden-IJssel & 34 & 26 & 22 & 18 \\
\hline Veluwe & 37 & 25 & 23 & 15 \\
\hline Arnhem/Oost-Gelderland & 35 & 27 & 23 & 16 \\
\hline Nijmegen/Rivierenland & 35 & 29 & 22 & 14 \\
\hline Flevoland & 37 & 31 & 23 & 9 \\
\hline Oost-Utrecht & 35 & 25 & 24 & 16 \\
\hline Midden- en West-Utrecht & 37 & 30 & 20 & 13 \\
\hline Gooi en Vechtstreek & 33 & 26 & 23 & 18 \\
\hline Noord-Holland Noord & 35 & 27 & 25 & 14 \\
\hline Amsterdam/Zaanstreek/Waterland & 36 & 31 & 20 & 13 \\
\hline Kennemer-/Amstel- en Meerlanden & 34 & 26 & 23 & 17 \\
\hline Rijnstreek & 36 & 27 & 23 & 15 \\
\hline Den Haag/Delft & 33 & 29 & 22 & 16 \\
\hline Drechtsteden & 37 & 26 & 23 & 14 \\
\hline Rijnmond & 36 & 27 & 23 & 14 \\
\hline Zeeland & 34 & 28 & 22 & 16 \\
\hline Westelijk Noord-Brabant & 35 & 28 & 22 & 15 \\
\hline Breda en omstreken & 37 & 27 & 24 & 13 \\
\hline Midden-Brabant & 37 & 27 & 23 & 13 \\
\hline Noord-Oost Brabant & 36 & 27 & 23 & 14 \\
\hline Zuid-Oost Brabant & 37 & 27 & 22 & 14 \\
\hline Midden- en Noord-Limburg & 35 & 27 & 23 & 15 \\
\hline Zuid-Limburg & 34 & 28 & 24 & 15 \\
\hline Totaal & 35 & 27 & 23 & 15 \\
\hline
\end{tabular}

Bran: CBS/ROA 
Tabel 21. Conjunctuurgevoeligheid per RBA-gebied

RBA-gebied

Conjunctuurindicator

Groningen

1.64

Friesland

1.67

Drenthe

1.68

IJssel-Vecht

1.67

Twente

$1.84 \quad 1+1$

Midden-IJssel

1.66

Veluwe

1.67

Arnhem/Oost-Gelderland

$1.711+1$

Nijmegen/Riviereniand

$1.731+1$

Flevoland

$1.48 \quad(-)$

Oost-Utrecht

1.64

$1.55 \quad(-)$

Midden- en West-Utrecht

1.61

Gooi en Vechtstreek

1.61

Noord-Holland Noord

$1.56 \quad(-)$

Amsterdam/Zaanstreek/Waterland

1.64

Kennemer-/Amstel- en Meerlanden

$1.56 \quad(-)$

Rijnstreek

$1.49 \quad(-)$

Den Haag/Delft

$1.751+1$

Rijnmond

1.64

Zeeland

1.70

Westelijk Noord-Brabant

$1.831+1$

Breda en omstreken

$1.74(+)$

Midden-Brabant

$1.831+1$

Noord-Oost Brabant

$1.751+1$

Zuid-Oost Brabant

$1.981+1$

Midden- en Noord-Limburg

$1.77(+)$

Zuid-Limburg

$1.801+1$

$+\quad=$ relatief hoge conjunctuurgevoeligheid

$=$ relatief lage conjunctuurgevoeligheid

Bron: ROA 
Tabel 22. Aantal werkenden en percentage van de totale werkgelegenheid per bedrijtssector voor het RBA-gebied Gooi en Vechtstreek (gemiddelde 1989-1990)

\begin{tabular}{|c|c|c|c|c|}
\hline Bedrijfssector & Aantal & $\%$ & & Trend \\
\hline Bouw & 6000 & 6 & \multirow{3}{*}{$1+1$} & \multirow{9}{*}{$\begin{array}{l}\text { sterk dalend } \\
\text { stijgend } \\
\text { constant } \\
\text { stijgend } \\
\text { constant } \\
\text { stijgend } \\
\text { constant } \\
\text { sterk dalend } \\
\text { sterk stijgend }\end{array}$} \\
\hline Handel & 18000 & 17 & & \\
\hline Vervoer en communicatie & 5000 & 5 & & \\
\hline Banken en verzekeringen & 5000 & 5 & \multirow{3}{*}{$1+1$} & \\
\hline Overige commerciële dienstverlening & 17000 & 16 & & \\
\hline Gezondheidszorg & 9000 & 8 & & \\
\hline Maatschappelijke dienstverlening & 12000 & 11 & \multirow[t]{3}{*}{$1+1$} & \\
\hline Openbaar bestuur, politie en defensie & 7000 & 7 & & \\
\hline Onderwijs & 6000 & 6 & & \\
\hline Totaal (incl. woningbezit en bedrijfssector onbekend) & 107000 & 100 & & \\
\hline$+\quad=$ relatief hoog ten opzichte van het landelijk $g$ & middelde & & & \\
\hline
\end{tabular}

Bron: CBS/ROA 
Tabel 23. Aantal werkenden en percentage van de totale werkgelegenheid per beroepsklasse voor het RBA-gebied Gooi en Vechtstreek (gemiddelde 1989-1990)

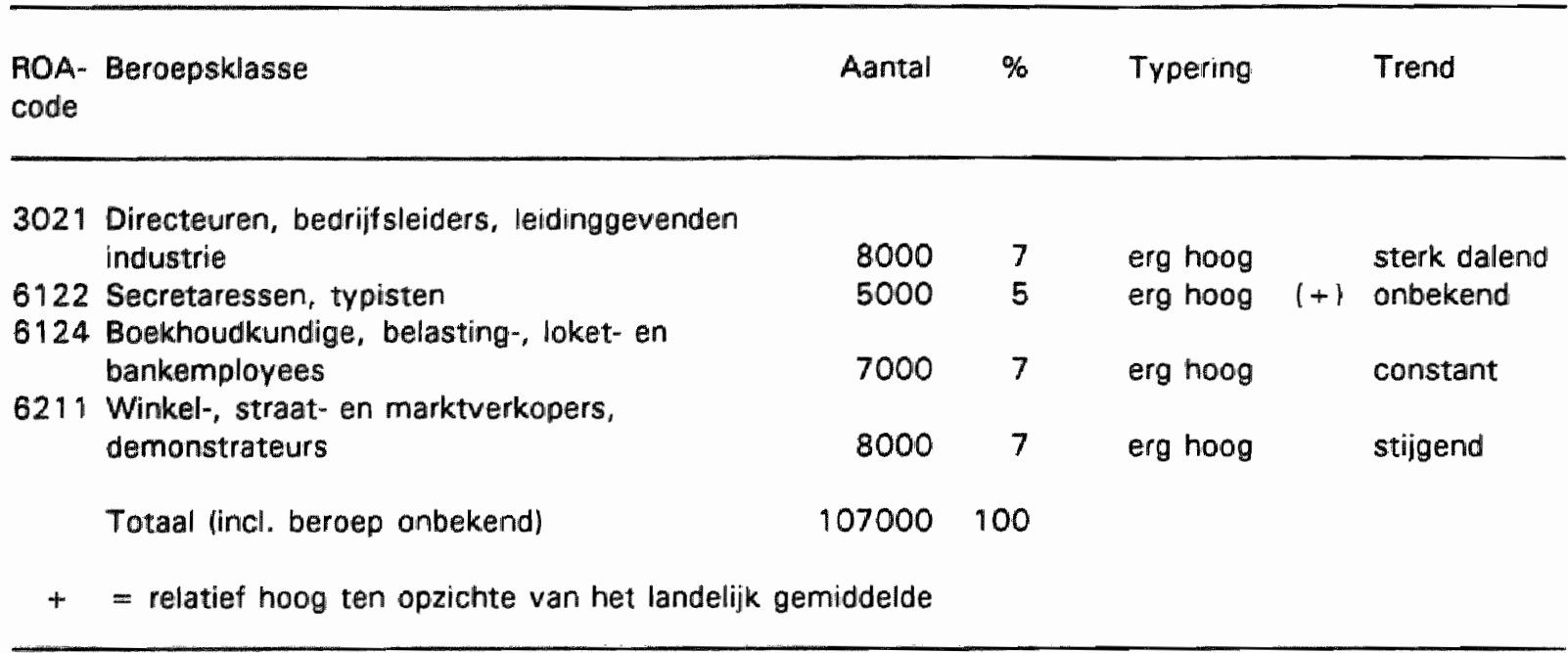

Bran: CBS/ROA 
$-59-$

Tabel 24. Aantal werkenden en percentage van de totale werkgelegenheid per opleidingstype voor het RBA-gebied Gooi en Vechtstreek 1990

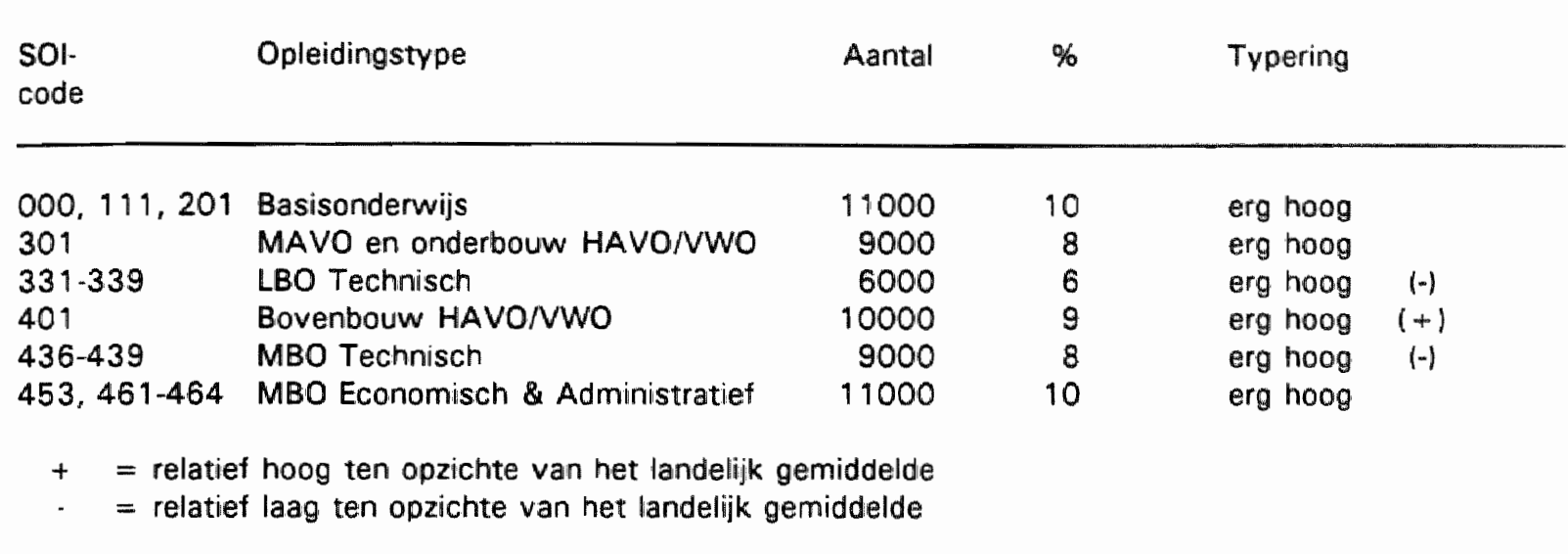


Tabel 25. Werkloosheidspercentage per opleidingstype voor het RBA-gebied Gooi en Vechtstreek april 1991 (bemiddelingsbestand zonder baan)

\begin{tabular}{|c|c|c|c|}
\hline $\begin{array}{l}\text { SOll- } \\
\text { code }\end{array}$ & Opleidingstype & $\%$ & Typering \\
\hline $000,111,201$ & Basisonderwijs & 13 & erg hoog \\
\hline 301 & MAVO en onderbouw HAVONWO & 11 & erg hoog \\
\hline 331.339 & LBO Technisch & 6 & gemiddeld \\
\hline 401 & Bovenbouw HAVONWW & 6 & gemiddeld \\
\hline $436-439$ & MBO Technisch & 1 & erg laag \\
\hline $453,461-464$ & MBO Economisch \& Administratief & 1 & erg laag \\
\hline
\end{tabular}


-61 -

Tabel 26. Bedriffssectorspreiding per opleidingstype voor het RBA-gebied Gooi en Vechtstreek 1990 (Gini-Hirschman indicator)

\begin{tabular}{llcl}
\hline $\begin{array}{l}\text { SOI- } \\
\text { code }\end{array}$ & Opleidingstype & $\begin{array}{c}\text { Gini-Hirschman } \\
\text { indicator }\end{array}$ & Typering \\
\hline $000,111,201$ & Basisonderwijs & 0.93 & groot \\
301 & MAVO en onderbouw HAVO/NWO & 0.92 & groot \\
$331-339$ & LBO Technisch & 0.91 & groot \\
401 & Bovenbouw HAVO/NWO & 0.90 & groot \\
$436-439$ & MBO Technisch & 0.92 & groot \\
$453,461-464$ & MBO Economisch \& Administratief & 0.89 & groot \\
\hline
\end{tabular}

Bron: ROA 
Tabel 27. Aantal werkenden en percentage van de totale werkgelegenheid per bedrijfssector voor het RBA-gebied Noord-Holland Noord (gemiddelde 1989-1990)

\begin{tabular}{lrrll} 
Bedrijfssector & Aantal & $\%$ & Trend \\
\hline Landbouw, visserij en bosbouw & 20000 & 8 & $(+1$ & dalend \\
Voedings- en genotmiddelenindustrie & 7000 & 3 & & constant \\
Metaalindustrie & 14000 & 6 & constant \\
Bouw & 18000 & 7 & dalend \\
Handel & 41000 & 16 & dalend \\
Vervoer en communicatie & 13000 & 5 & constant \\
Banken en verzekeringen & 9000 & 4 & dalend \\
Horeca & 8000 & 3 & sterk stijgend \\
Overige commerciële dienstverlening & 27000 & 11 & constant \\
Gezondheidszorg & 18000 & 7 & constant \\
Maatschappelijke dienstverlening & 20000 & 8 & $1+1$ & constant \\
Openbaar bestuur, politie en defensie & 26000 & 10 & 5 & \\
Onderwijs & 13000 & 5 & \\
Totalal (incl. woningbezit en bedrijfssector onbekend) & 252000 & 100 & \\
$\quad+\quad=$ relatief hoog ten opzichte van het landelijk gemiddelde & &
\end{tabular}

Bron: CBS/ROA 
$-63-$

Tabel 28. Aantal werkenden en percentage van de totale werkgelegenheid per beroepsklasse voor het RBA-gebied Noord-Holland Noord (gemiddelde 1989-1990)

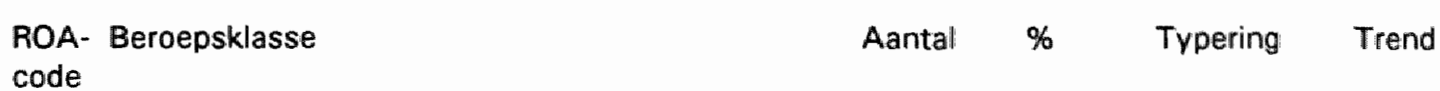

0132 Docenten voortgezet en hoger onderwijs

\begin{tabular}{|c|c|c|c|}
\hline $\begin{array}{r}7000 \\
11000 \\
9000\end{array}$ & $\begin{array}{l}3 \\
4 \\
3\end{array}$ & $\begin{array}{l}\text { hoog } \\
\text { erg hoog } \\
\text { erg hoog }\end{array}$ & $\begin{array}{l}\text { dalend } \\
\text { dalend } \\
\text { dalend }\end{array}$ \\
\hline $\begin{array}{r}14000 \\
5000 \\
5000\end{array}$ & $\begin{array}{l}5 \\
2 \\
2\end{array}$ & $\begin{array}{l}\text { erg hoog } \\
\text { hoog } \\
\text { hoog }\end{array}$ & $\begin{array}{l}\text { sterk stijgend } \\
\text { constant } \\
\text { constant }\end{array}$ \\
\hline $\begin{array}{l}6000 \\
6000\end{array}$ & $\begin{array}{l}2 \\
2\end{array}$ & $\begin{array}{l}\text { hoog } \\
\text { hoog }\end{array}$ & $\begin{array}{l}\text { constant } \\
\text { constant }\end{array}$ \\
\hline $\begin{array}{l}16000 \\
12000\end{array}$ & $\begin{array}{l}6 \\
5\end{array}$ & $\begin{array}{l}\text { erg hoog } \\
\text { erg hoog }\end{array}$ & $\begin{array}{l}\text { dalend } \\
\text { constant }\end{array}$ \\
\hline $\begin{array}{r}18000 \\
7000 \\
7000\end{array}$ & $\begin{array}{l}7 \\
3 \\
3\end{array}$ & $\begin{array}{l}\text { erg hoog } \\
\text { hoog } \\
\text { erg hoog }\end{array}$ & $\begin{array}{l}\text { stijgend } \\
\text { dalend } \\
\text { constant }\end{array}$ \\
\hline 10000 & 4 & erg hoog & constant \\
\hline 7000 & 3 & hoog & dalend \\
\hline 252000 & 100 & & \\
\hline
\end{tabular}

2011 Uitvoerend agrarisch personeel, bosarbeider

2012 Zelfstandige agrariërs, boswachters

3021 Directeuren, bedrijfsleiders, leidinggevenden industrie

3312 Houtbewerkers, timmerlieden

4211 Conducteurs, chauffeurs e.a. transportmiddelenbestuurders

5021 Gediplomeerde verpleegkundigen, verloskundigen

6124 Boekhoudkundige, belasting-, loket- en bankemployees

6125 Commercieel-administratieve employees

6211 Winkel-, straat- en marktverkopers, demonstrateurs

6221 Winkeliers e.a. detail- en groothandelaren

8111 Koks, kelners e.a. keuken- en serveerpersoneel

8211 Portiers, schoonmaak- e.a. lager dienstverlenend personeel

8212 Kinder-, gezins-, bejaardenverzorgenden e.a. verzorgend personeel

Totaal (incl. beroep onbekend) 
$-64-$

Tabel 29. Aantal werkenden en percentage van de totale werkgelegenheid per opleidingstype voor het RBA-gebied Noord-Holland Noord 1990

\begin{tabular}{|c|c|c|c|c|}
\hline $\begin{array}{l}\text { SOl- } \\
\text { code }\end{array}$ & Opleidingstype & Aantal & $\%$ & Typering \\
\hline $000,111,201$ & Basisonderwijs & 24000 & 10 & erg hoog \\
\hline 301 & MAVO en onderbouw HAVOMWO & 23000 & 9 & erg hoog \\
\hline 321.329 & LBO Agrarisch & 6000 & 2 & hoog \\
\hline $331-339$ & LBO Technisch & 20000 & 8 & erg hoog \\
\hline $361-369$ & LBO Economisch-Administratief & 7000 & 3 & hoog \\
\hline $381-389$ & LBO Verzorgend & 12000 & 5 & erg hoog \\
\hline 401 & Bovenbouw HAVO/WWO & 11000 & 4 & hoog \\
\hline 421.429 & MBO Agrarisch & 7000 & 3 & hoog \\
\hline $436-439$ & MBO Technisch & 30000 & 12 & erg hoog \\
\hline 451,454 & MBO Verpleging \& Ziekenverzorging & 8000 & 3 & hoog \\
\hline $453,461-464$ & MBO Economisch \& Administratief & 29000 & 12 & erg hoog \\
\hline $481,484,486$ & MBO Verzorgend & 12000 & 5 & erg hoog \\
\hline
\end{tabular}

Bron: CBS/ROA 
$-65-$

Tabel 30. Werkloosheidspercentage per opleidingstype voor het RBA-gebied Noord-Hoiland Noord april 1991 (bemiddelingsbestand zonder baan)

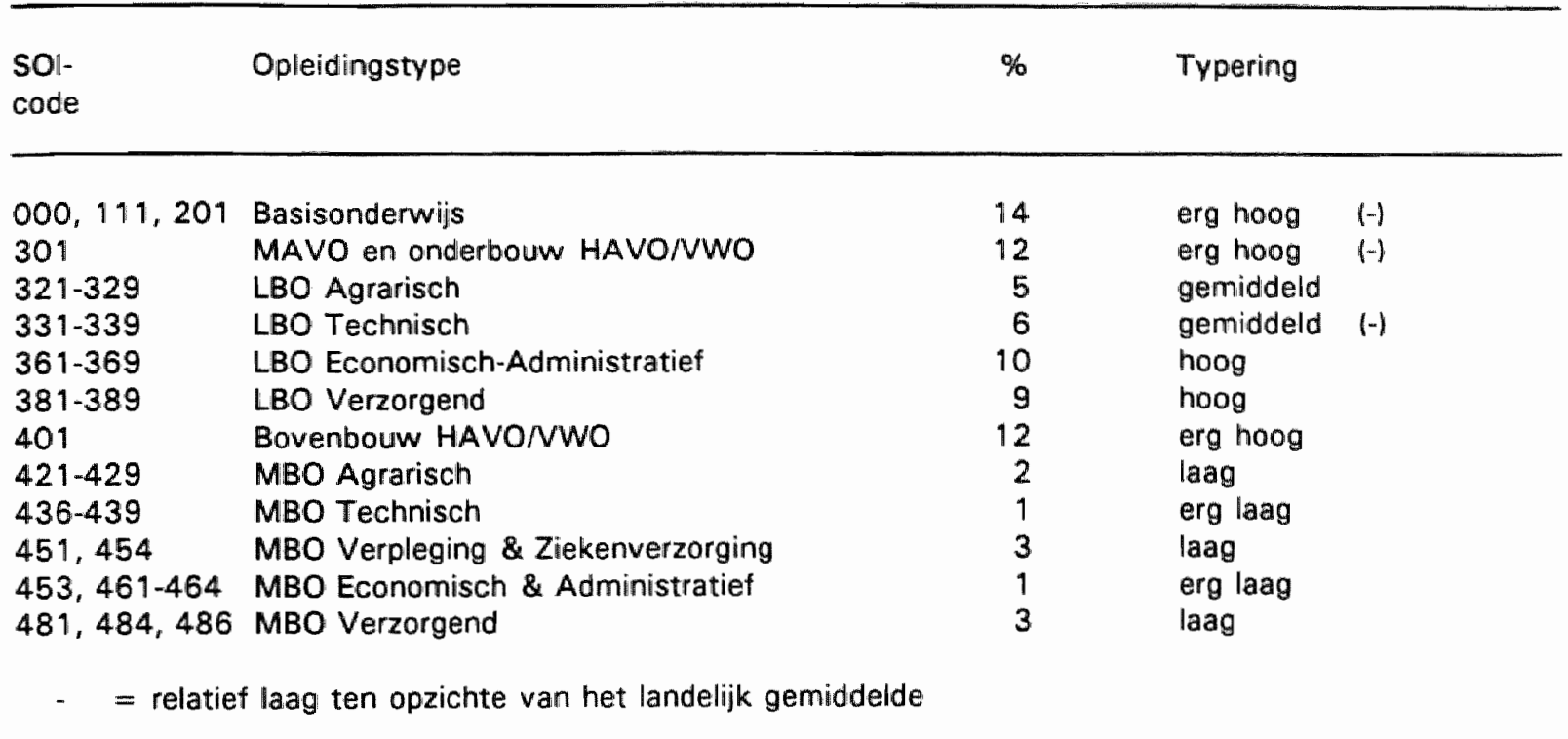

Bron: Arbeidsvoorzieningsorganisatie/ROA 
$-66-$

opleidingstype voor het RBA-gebied Noord-Holland Noord 1990

\begin{tabular}{lll}
\hline & $\begin{array}{c}\text { Gini-Hirschman } \\
\text { indicator }\end{array}$ & Typering \\
\hline IVO/NWO & 0.96 & erg groot \\
& 0.93 & groot \\
stratief & 0.72 & gemiddeld \\
& 0.93 & groot \\
& 0.85 & gemiddeld \\
& 0.90 & groot \\
nverzorging & 0.94 & groot \\
inistratief & 0.69 & klein \\
& 0.93 & groot \\
& 0.56 & klein \\
& 0.93 & groot \\
& 0.83 & gemiddeld \\
\hline
\end{tabular}


$-67$.

Tabel 32. Aantal werkenden en het percentage van de totale werkgelegenheid per bedrijfssector voor het RBA-gebied Amsterdam/Zaanstreek/Waterland (gemiddelde 1989-1990)

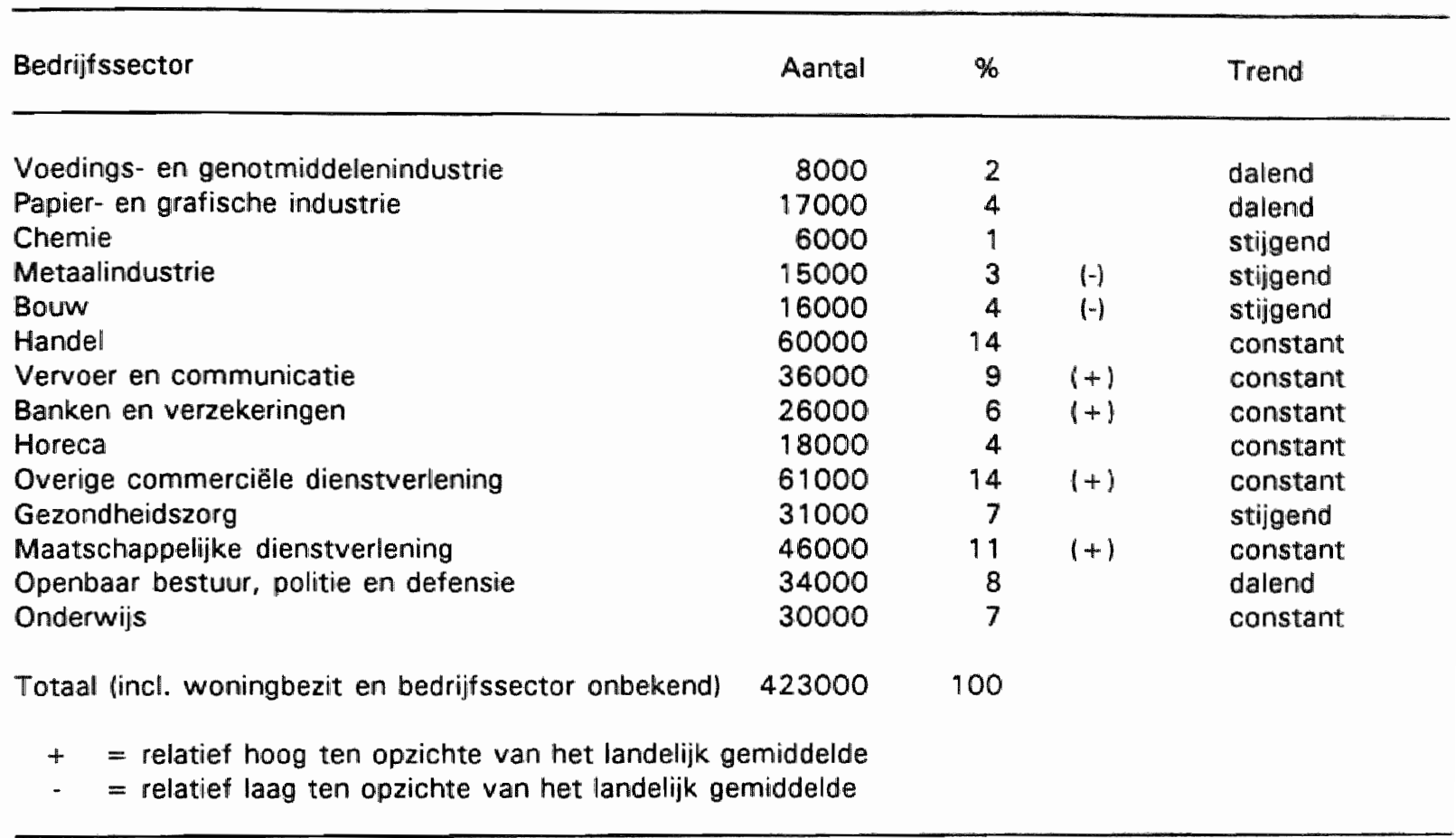

Bron: CBS/ROA 
Tabel 33. Aantal werkenden en percentage van de totale werkgelegenheid per beroepsklasse voor het RBA-gebied Amsterdam/Zaanstreek/Waterland (gemiddelde 1989-1990)

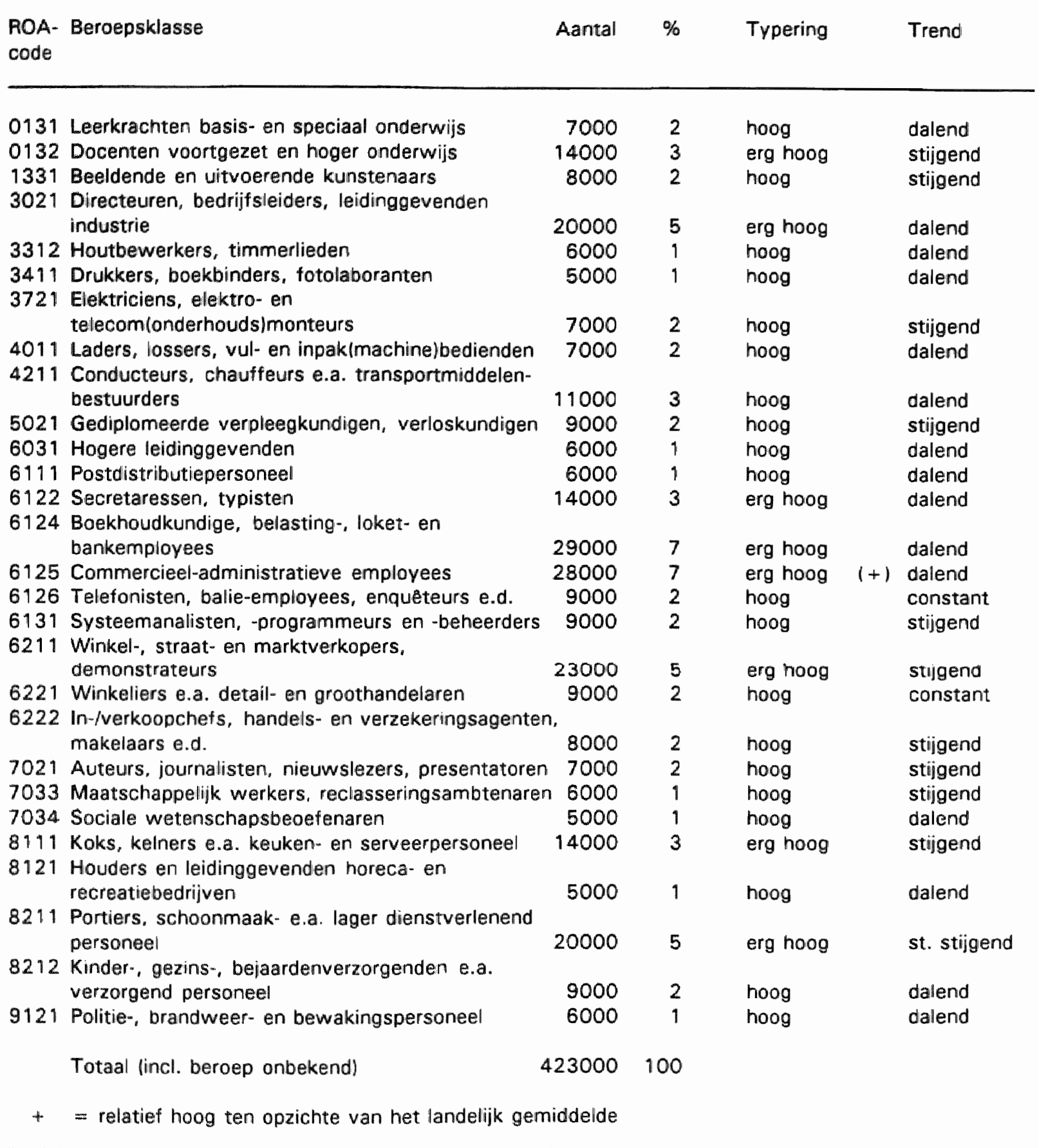

Bron: CBS/ROA 
$-69-$

Tabel 34. Aantal werkenden en percentage van de totale werkgelegenheid per opleidingstype voor het RBA-gebied Amsterdam/Zaanstreek/Waterland 1990

\begin{tabular}{|c|c|c|c|c|c|}
\hline $\begin{array}{l}\text { SOI- } \\
\text { code }\end{array}$ & Opleidingstype & Aantal & $\%$ & Typering & \\
\hline $\begin{array}{l}000,111,201 \\
301 \\
331-339 \\
361-369 \\
381-389 \\
401 \\
436-439 \\
451,454 \\
453,461-464 \\
481,484,486\end{array}$ & $\begin{array}{l}\text { Basisonderwijs } \\
\text { MAVO en onderbouw HAVO/VWO } \\
\text { LBO Technisch } \\
\text { LBO Economisch-Administratief } \\
\text { LBO Verzorgend } \\
\text { Bovenbouw HAVO/VWO } \\
\text { MBO Technisch } \\
\text { MBO Verpleging \& Ziekenverzorging } \\
\text { MBO Economisch \& Administratief } \\
\text { MBO Verzorgend }\end{array}$ & $\begin{array}{l}45000 \\
37000 \\
26000 \\
10000 \\
13000 \\
41000 \\
35000 \\
10000 \\
44000 \\
10000\end{array}$ & $\begin{array}{r}10 \\
8 \\
6 \\
2 \\
3 \\
9 \\
8 \\
2 \\
10 \\
2\end{array}$ & $\begin{array}{l}\text { erg hoog } \\
\text { erg hoog } \\
\text { erg hoog } \\
\text { hoog } \\
\text { hoog } \\
\text { erg hoog } \\
\text { erg hoog } \\
\text { hoog } \\
\text { erg hoog } \\
\text { hoog }\end{array}$ & $\begin{array}{c}1+1 \\
1-1\end{array}$ \\
\hline
\end{tabular}

Bron: CBS/ROA 
Tabel 35. Werkloosheidspercentage per opleidingstype voor het RBA-gebied Amsterdam/Zaanstreek' Waterland april 1991 (bemiddelingsbestand zonder baan\}

\begin{tabular}{|c|c|c|}
\hline $\begin{array}{l}\text { SOl- } \\
\text { code }\end{array}$ & Opleidingstype & $\%$ \\
\hline
\end{tabular}

$\begin{array}{ll}\text { O00, 111, 201 } & \text { Basisonderwijs } \\ 301 & \text { MAVO en onderbouw HAVO/MWO } \\ 331-339 & \text { LBO Technisch } \\ 361-369 & \text { LBO Economisch-Administratief } \\ 381-389 & \text { LBO Verzorgend } \\ 401 & \text { Bovenbouw HAVO/NWO } \\ 436-439 & \text { MBO Technisch } \\ 451,454 & \text { MBO Verpleging \& Ziekenverzorging } \\ 453,461-464 & \text { MBO Economisch \& Administratief } \\ 481,484,486 & \text { MBO Verzorgend }\end{array}$

$\begin{array}{lll}36 & \text { erg hoog } & 1+1 \\ 29 & \text { erg hoog } & 1+1 \\ 17 & \text { erg hoog } & 1+1 \\ 21 & \text { erg hoog } & 1+1 \\ 17 & \text { erg hoog } & 1+1 \\ 23 & \text { erg hoog } & 1+1 \\ 4 & \text { gemiddeld } & 1+1 \\ 4 & \text { gemiddeld } & 1+1 \\ 2 & \text { laag } & \\ 6 & \text { gemiddeld } & 1+1\end{array}$

$+\quad=$ relatief hoog ten opzichte van het landelijk gemiddelde

Bron: Arbeidsvoorzieningsorganisatie/ROA 
Tabel 36. Bedrijfssectorspreiding per opleidingstype voor het RBA-gebied Amsterdam/Zaanstreek/ Waterland 1990 (Gini-Hirschman indicator)

\begin{tabular}{llll}
\hline $\begin{array}{l}\text { SOI- } \\
\text { code }\end{array}$ & Opleidingstype & $\begin{array}{c}\text { Gini-Hirschman } \\
\text { indicator }\end{array}$ & Typering \\
\hline 000, 111, 201 & Basisonderwijs & & groot \\
301 & MAVO en onderbouw HAVO/VWO & 0.94 & groot \\
$331-339$ & LBO Technisch & 0.94 & groot \\
$361-369$ & LBO Economisch-Administratief & 0.94 & groot \\
$381-389$ & LBO Verzorgend & 0.89 & groot \\
401 & Bovenbouw HAVO/VWO & 0.91 & groot \\
$436-439$ & MBO Technisch & 0.93 & erg klein \\
451,454 & MBO Verpleging \& Ziekenverzorging & 0.94 & groot \\
$453,461-464$ & MBO Economisch \& Administratief & 0.45 & groot
\end{tabular}

Bron: ROA 
Tabel 37. Aantal werkenden en percentage van de totale werkgelegenheid per bedrijfssector voor het RBA-gebied Kennemer-/Amstel- en Meerlanden (gemiddelde 1989-1990)

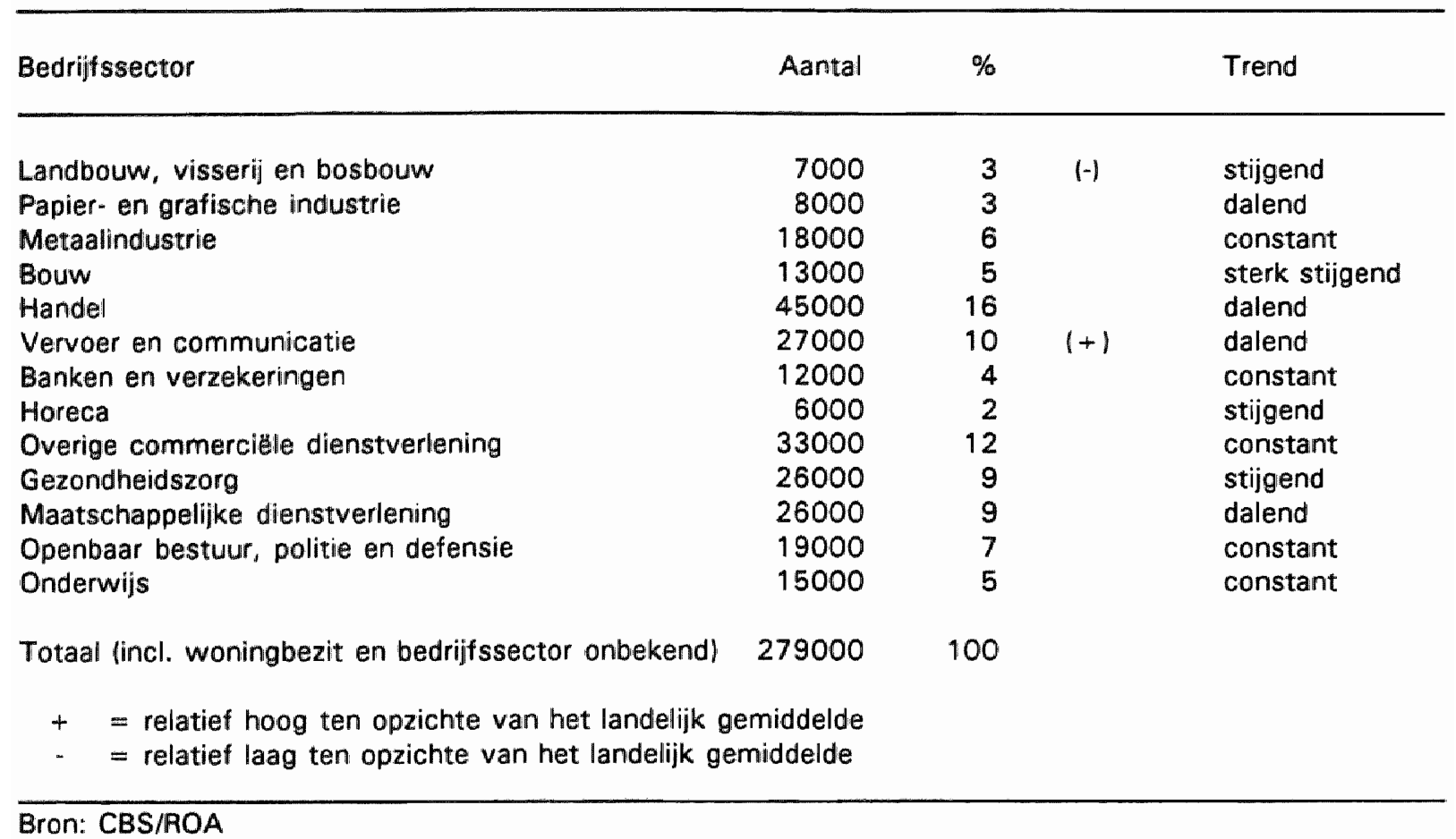


Tabel 38. Aantal werkenden en percentage van de totale werkgelegentheid per beroepsklasse voor het RBA-gebied Kennemer-/Amstel- en Meerlanden (gemiddelde 1989-1990)

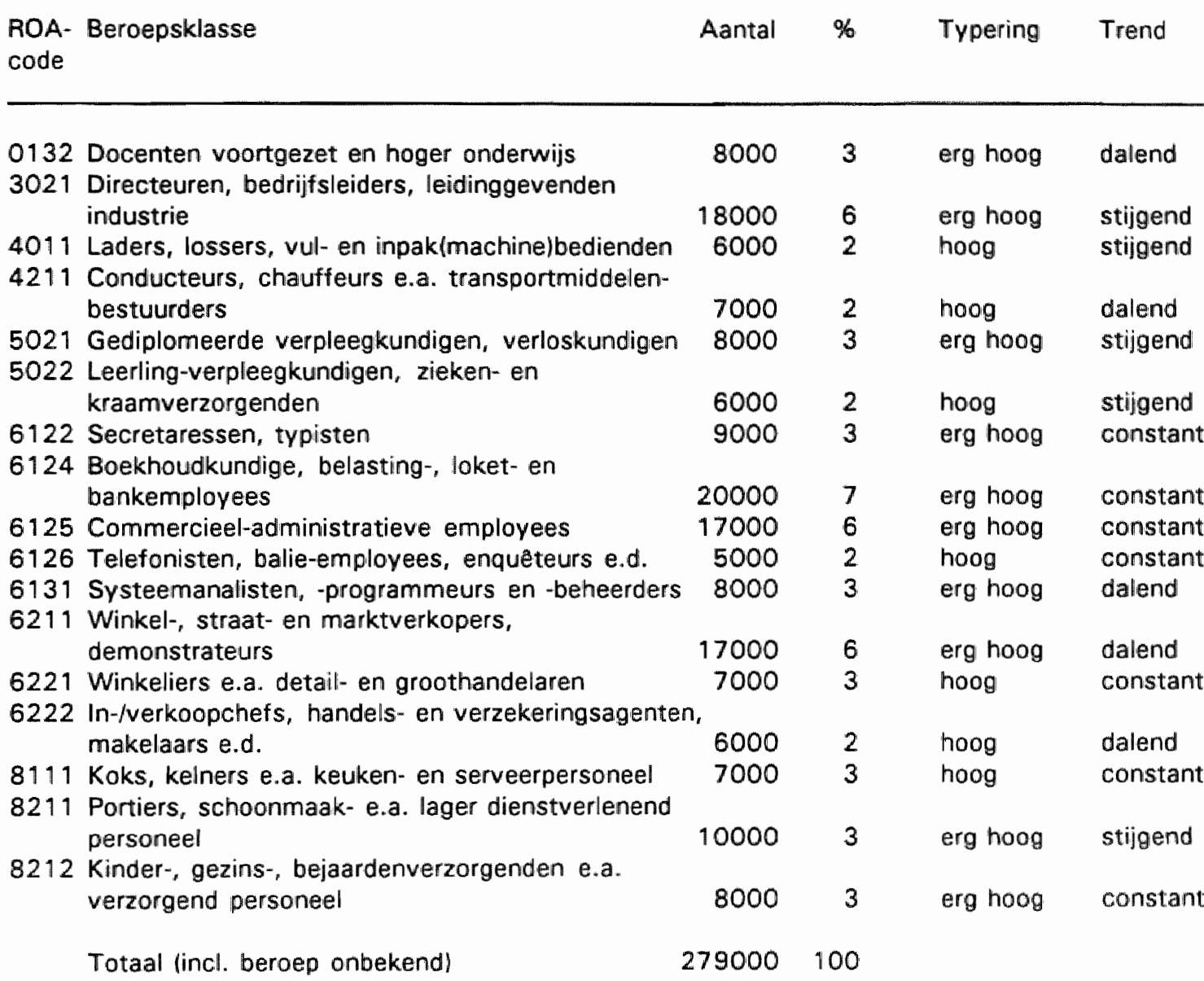


Tabel 39. Aantal werkenden en percentage van de totale werkgelegenheid per opleidingstype voor het RBA-gebied Kennemer-/Amstel- en Meerlanden 1990

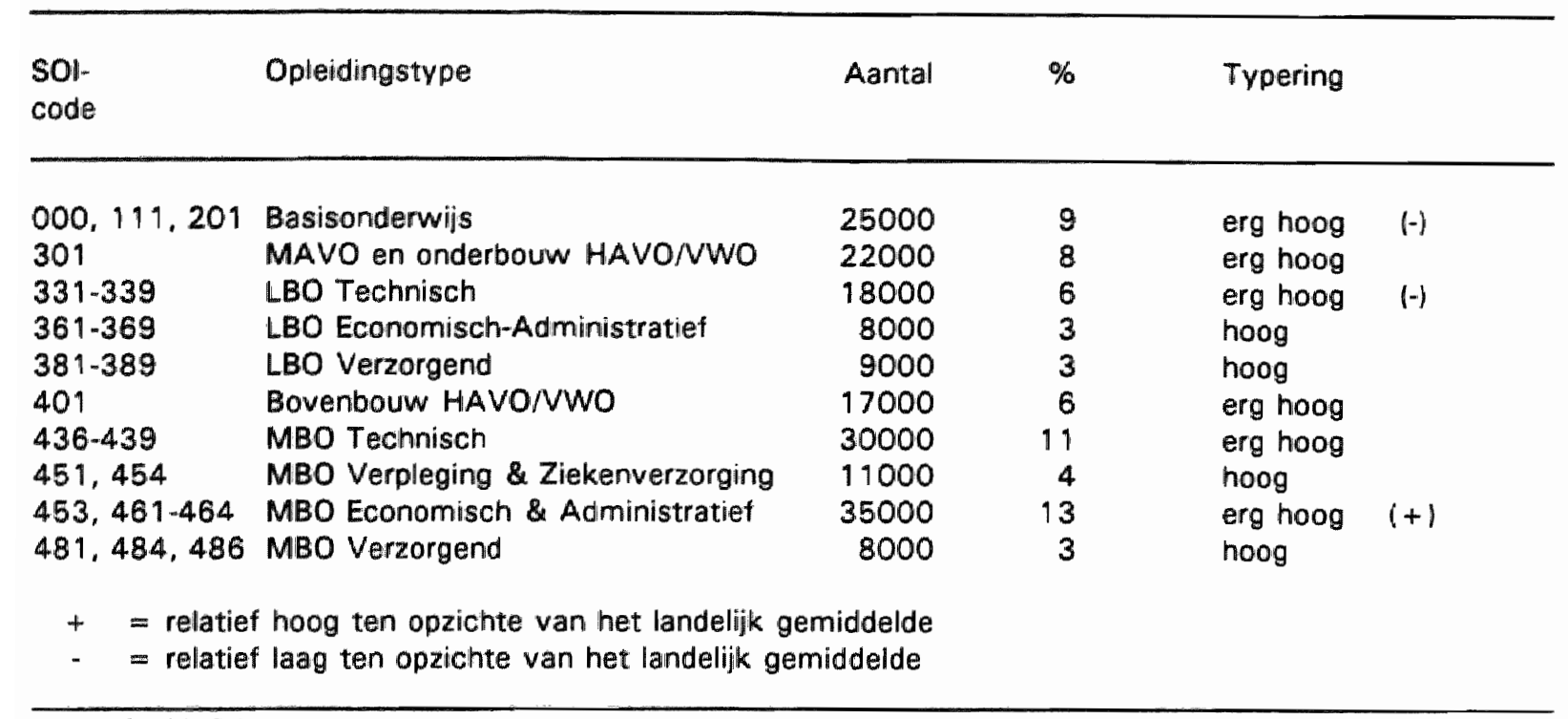

Bron: CBS/ROA 
$-75-$

Tabel 40. Werkloosheidspercentage per opleidingstype voor het RBA-gebied Kennemer-/Amstel- en Meerlanden april 1991 (bemiddelingsbestand zonder baan)

\begin{tabular}{|c|c|c|c|c|}
\hline $\begin{array}{l}\text { SOI- } \\
\text { code }\end{array}$ & Opleidingstype & $\%$ & Typering & \\
\hline $\begin{array}{l}000,111,201 \\
301 \\
331-339 \\
361-369 \\
381-389 \\
401 \\
436-439 \\
451,454 \\
453,461-464 \\
481,484,486\end{array}$ & $\begin{array}{l}\text { Basisonderwijs } \\
\text { MAVO en onderbouw HAVO/VWO } \\
\text { LBO Technisch } \\
\text { LBO Economisch-Administratief } \\
\text { LBO Verzorgend } \\
\text { BOvenbouw HAVO/NWO } \\
\text { MBO Technisch } \\
\text { MBO Verpleging \& Ziekenverzorging } \\
\text { MBO Economisch \& Administratief } \\
\text { MBO Verzorgend }\end{array}$ & $\begin{array}{r}11 \\
9 \\
4 \\
6 \\
6 \\
7 \\
1 \\
1 \\
1 \\
2\end{array}$ & $\begin{array}{l}\text { erg hoog } \\
\text { hoog } \\
\text { gemiddeld } \\
\text { gemiddeld } \\
\text { gemiddeld } \\
\text { gemiddeld } \\
\text { erg laag } \\
\text { erg laag } \\
\text { erg laag } \\
\text { laag }\end{array}$ & $\begin{array}{l}(-1) \\
(-1) \\
(-1) \\
(-1) \\
(-1) \\
(-1)\end{array}$ \\
\hline
\end{tabular}

Bron: Arbeidsvoorzieningsorganisatie/ROA 
Tabel 41. Bedrijfssectorspreiding per opleidingstype

voor het RBA-gebied Kennemer-/Amstel- en Meerlanden 1990 (Gini-Hirschman indicator)

\begin{tabular}{llcl}
\hline $\begin{array}{l}\text { SOI- } \\
\text { code }\end{array}$ & Opleidingstype & $\begin{array}{c}\text { Gini-Hirschman } \\
\text { indicator }\end{array}$ & Typering \\
\hline $000,111,201$ & Basisonderwijs & 0.94 & groot \\
301 & MAVO en onderbouw HAVO/VWO & 0.93 & groot \\
$331-339$ & LBO Technisch & 0.92 & groot \\
$361-369$ & LBO Economisch-Administratief & 0.92 & groot \\
$381-389$ & LBO Verzorgend & 0.92 & groot \\
401 & Bovenbouw HAVO/VWO & 0.94 & groot \\
$436-439$ & MBO Technisch & 0.94 & groot \\
451,454 & MBO Verpleging \& Ziekenverzorging & 0.55 & erg klein \\
$453,461-464$ & MBO Economisch \& Administratief & 0.92 & groot \\
$481,484,486$ & MBO Verzorgend & 0.78 & gemiddeld
\end{tabular}

Bron: ROA 